\title{
Innovation through new blood
}

\author{
Martijn J. Smit ${ }^{1,2}$
}

Received: 22 April 2016 / Accepted: 13 January 2017 / Published online: 14 February 2017

(C) The Author(s) 2017. This article is published with open access at Springerlink.com

\begin{abstract}
We model the influence of employee mobility on the transmission of knowledge between firms, assuming human capital to be an important influence on service innovation and firm productivity. To this end, we follow individual workers as they move from firm to firm, controlling for knowledge characteristics ('absorptive capacity') of the firm and for regional effects (agglomeration and urbanization). We measure the amount and variety of such flows, and we find statistically significant results; yet the impact of new employees on innovation and productivity seems to come more from the diversity of source firms than from the number of new employees, and effects differ markedly between small and larger firms.
\end{abstract}

JEL Classification R10 $\cdot \mathrm{O} 33 \cdot \mathrm{D} 22$

\section{Introduction}

Labour mobility can be a prime source of new ideas and new knowledge for a firm. Peter Hall extensively describes how Silicon Valley in its early years thrived on employees that moved seamlessly between different start-ups (Hall 1998, pp. 435-446). The more closed culture of the competing Route 128 cluster is often seen as a cause for its decline (Saxenian 1996).

$凶$ Martijn J. Smit

m.j.smit@uu.nl

1 Department of Human Geography and Spatial Planning, Utrecht University, Heidelberglaan 2, 3584 CS Utrecht, The Netherlands

2 Department of Spatial Economics, Vrije Universiteit Amsterdam, Amsterdam, The Netherlands 
A broad range of literature, discussed below, has asked the question whether attracting new employees benefits a firm. The diversity of such inflows, where a receiving firm gains access to a diverse range of sources, has undeservedly not played a role in this literature. Hence, our key question is whether receiving new employees from a range of source firms is important for the success of the receiving firm.

In addition, we believe the heterogeneity of such effects on firms of different sizes and sectors, and the contrast with traditional 'black box' agglomeration measures deserves more attention. Subtleties of academic argumentation are all too often lost in translation to policies, and correlations which are only valid in certain settings are too easily taken for universal laws. Instead, heterogeneous effects should have important policy implications.

We therefore study the impact of new employees on the innovative and productive performance of firms. Besides the number of new employees, we include their diversity of source firms, and we are able to contrast this with the diversity of firms in the region. We then separate out the results for productivity by firm size and sector to test whether the effects are universal.

The paper is organized as follows: Sect. 2 discusses the literature on employee mobility; Sect. 3 discusses the analysis at hand; Sect. 4 describes the data sources; Sect. 5 presents the results; and Sect. 6 concludes.

\section{The literature}

The channels through which knowledge spills over between firms have been studied extensively in the past (Glaeser et al. 1992; Paci and Usai 1999; van Oort 2002). Geographical proximity is often said to be a factor (Beaudry and Breschi 2003; Jaffe et al. 1993), and the agglomeration literature has focused on this (Rosenthal and Strange 2004; de Groot et al. 2015). However, many claim other types of proximity matter as well, including networks (Boschma 2005; Castells 1996). In such networks, some studies focus on the sources of spillovers (Anselin et al. 1997; Ponds et al. 2010), others on the receiving end (Smit et al. 2015). We could easily argue the flow itself is even more important; it is just a pity that it rarely leaves a 'paper trail' (Jaffe et al. 1993).

Yet it is has been widely claimed that we actually know one of the channels of knowledge spillovers: human capital (Ettlie 1980; Breschi and Lissoni 2001; Youl Lee et al. 2004; Malmberg and Power 2005; Beckstead et al. 2008). Employees 'contain' tacit knowledge (Sheshinski 1967) and are one of the carriers of the 'routines' of a firm - the equivalent of biological DNA, in the vocabulary of evolutionary economists (Nelson and Winter 2009). Such routines are formed when the firm conducts its business, whether that concerns industrial production processes (where we can think of Ford's conveyor belt) or services offered (e.g. financial products). Developing new routines through innovation (whether planned or spontaneous) is costly and slow compared to copying routines from other firms. Hence, such copying behaviour is a viable strategy for firms. As an example, Klepper showed that spinoffs in the Detroit car manufacturing sector are more successful than other start-ups, suggesting they may be building upon the routines of successful existing firms, making their productivity higher from 
Table 1 Some earlier studies on the effects of labour mobility

\begin{tabular}{|c|c|c|c|c|c|c|}
\hline Study & Year & Dependent & Flow & Region & Sector & Period \\
\hline $\begin{array}{l}\text { Kronenberg } \\
\text { and Carree }\end{array}$ & (2010a) & $\begin{array}{l}\text { Labour } \\
\text { productivity }\end{array}$ & Employees & Netherlands & Manufacturing & $2002-2005$ \\
\hline $\begin{array}{l}\text { Boschma et } \\
\text { al. }\end{array}$ & (2009) & $\begin{array}{l}\text { Labour } \\
\text { productivity }\end{array}$ & $\begin{array}{r}\text { Employees } \\
\text { (sectoral) }\end{array}$ & Sweden & All & 1988-2004 \\
\hline $\begin{array}{l}\text { Stoyanov and } \\
\text { Zubanov }\end{array}$ & (2012) & Productivity & $\begin{array}{l}\text { Sum of absolute } \\
\text { productivity gap }\end{array}$ & Denmark & Manufacturing & 1995-2007 \\
\hline Bjerke & (2012) & Productivity & $\begin{array}{l}\text { Employees (all, } \\
\text { creative, } \\
\text { high-education) }\end{array}$ & Sweden & $\begin{array}{c}\text { KIBS versus } \\
\text { non-KIBS }\end{array}$ & 2002-2008 \\
\hline $\begin{array}{c}\text { Eriksson and } \\
\text { Lindgren }\end{array}$ & (2009) & $\begin{array}{l}\text { Labour } \\
\text { productivity, } \\
\text { wages }\end{array}$ & Employees & Sweden & All & 1985-2003 \\
\hline Kaiser et al. & (2008) & Patents & $\begin{array}{l}\text { R\&D/other } \\
\text { employees }\end{array}$ & Denmark & $\begin{array}{l}\text { All sectors with } \\
\text { patents }\end{array}$ & 1999-2002 \\
\hline Song et al. & (2003) & $\begin{array}{l}\text { Patent } \\
\text { citations }\end{array}$ & Engineers & US/non-US & Semiconductors & 1980-1999 \\
\hline
\end{tabular}

the outset (Klepper 2007). These routines are embedded in the employees, but they can also bring along less tacit knowledge as they move from one firm to another-legally or illegally. Moreover, they can form a link back to their previous employer to channel knowledge to their new firm, e.g. by keeping in contact with former colleagues (Reinau 2011), or when both employers cooperate (Somaya et al. 2008). For this reason, employees are sometimes specifically forbidden to gain employment within the same sector after leaving a firm (Bishara and Westermann-Behaylo 2012). But such 'poaching' can be beneficial to firms on the whole: Combes and Duranton (2006) show in a modelling approach that firms can benefit from agglomeration yet at the same time suffer even more from the poaching of workers by competitors and the higher wages they have to pay their valuable employees in order to convince them to stay. However, even without poaching a firm will often end up with employees from its competitors. Simply looking for new employees who can do the job at hand, they will often find them within their cluster, since labour mobility is more intense within clusters (Power and Lundmark 2004). The knowledge spillover is then a side effect.

Job mobility from an employee perspective has been studied in several earlier studies. Six key papers are summarized in Table 1, and we will discuss these as well as several other papers with a more specific focus.

Kronenberg and Carree (2010a) looked at the Netherlands in a working paper, focusing on labour flows within the manufacturing sector. Importantly, they discover that flows within the same narrow 5-digit sector have a positive and statistically significant impact; this concerns about $12 \%$ of the total labour flows. Similarly, Boschma et al. (2009) show Swedish firms become more productive through an inflow of employees with skills related (but not identical) to those already available within the company; and Stoyanov and Zubanov (2012) found significantly positive effects for Denmark, again in particular for intra-industry flows. They also indicate effects are more positive 
for more educated and skilled workers. This is confirmed by Bjerke (2012, chapter 4), who shows that it can be especially beneficial to attract new employees to perform tasks in the new firm that are related (but not identical) to those they performed in their old firm. Likewise, Eriksson and Lindgren (2009) focus on the effect of the environment: within in a cluster, labour flows within and across industries are the most important contribution to increased productivity.

Several studies zoom in even further on R\&D employees, thought to be the prime bearers of knowledge. Kaiser et al. (2008) conclude 16 new R\&D workers who previously were 'exposed to' patenting lead to a new patent for the receiving firm, on average. Maliranta et al. (2009) show that hiring R\&D staff from competitors can be beneficial for a firm, but only if their new job is outside a dedicated R\&D office. Similarly, Rosenkopf and Almeida (2003) study the mobility of inventors in the semiconductor industry as a conscious effort by firms to broaden their knowledge base into unknown territories. Interestingly, they conclude a large technological distance offers the largest benefit. Song et al. (2003) follow patenting engineers who moved between firms, and they too conclude that these new engineers allow firms to broaden their patenting activities, with the largest benefit when they come from technologically more distant firms. ${ }^{1}$

\section{Our model}

We emphasize two improvements on the existing literature. First of all, we focus on the effect the diversity of new employees has. Previous studies overlooked this aspect, with only one exception. Instead, they mainly consider the total flow of employees, sometimes with particular characteristics singled out. But it is obvious there must be a diseconomy of scale when receiving many employees from the same source, as the amount of new knowledge transferred by every additional employee becomes smaller and smaller. Therefore, we argue in line with the Schumpeter (1934) and Jacobs (1969) that a diversity of ideas can lead to new combinations; a lack of new ideas will lead to a situation of lock-in (Grabher 1993; Saxenian 1994; Nooteboom 2000). Although Jacobs was thinking rather of new ideas arising within the firm, branching out and breaking away into new firms and sectors, her work has often been applied to plain sectoral diversity within regions, especially following the seminal work of Glaeser et al. (1992). The contribution of Glaeser et al. (1992) was in particular to contrast a variety of industries with the co-location of similar industries (Beaudry and Schiffauerova 2009). Although that debate can not be settled conclusively (de Groot et al. 2015), there is a clear idea that variety is beneficial in many settings, perhaps in particular when the distance between sectors (or ideas) is not too large (Frenken et al. 2007). On the level of employees, several studies have discussed the diversity of existing staff, and results are mixed: it often matters, for example when looking at the impact of employee diversity in education and gender on innovation (Østergaard et al. 2011), or the impact of cultural diversity on patenting (Parrotta et al. 2014) and productivity (Trax et al. 2015), but Østergaard et al. (2011) find no effect of cultural diversity. It is

\footnotetext{
1 We should however note that there are also studies that claim the opposite for the firm level (Nesta 2008).
} 
a small but important step to combine the diversity of knowledge flows with that of a diverse workforce, and thus, we therefore argue a diversity of new employees will be beneficial for the receiving firm's productivity and innovation rate. In this respect, we work in the same direction as Boschma et al. (2009), except that they focused on the sectoral diversity, where we consider diversity among the source firms, as has been suggested in theoretical contributions by Kogut and Zander (1992) when discussing firms, and by Zahra and George (2002, p. 191) when discussing the diversity of sources in general.

A second contribution is indeed that we look at productivity and innovation in tandem. Although Ettlie (1980) in the management literature focused on innovation as the outcome, most studies focus on productivity instead, arguing this to be the final outcome, to be preferred above intermediates such as patents (Stoyanov and Zubanov 2012). However, Ettlie did indicate several interesting avenues of research, in particular suggesting manpower flows will have stronger effects on major compared to minor innovations (pp. 1088 and 1093). Table 1 shows how all key studies either look at patents or take the (labour) productivity route. We however will study both innovations and productivity. This allows us to distinguish between effects that are beneficial for innovation, but do not lead to productivity increases; effects that increase productivity, but not through innovation; and effects that affect both or neither. We will also subdivide innovations into more radical innovations, in the sense that they are new to the market, and innovations that are new to the firm, again in line with Ettlie (1980).

\subsection{Dependents}

We estimate the effects of labour mobility on four dependents: service innovations new to the firm, ${ }^{2}$ product innovations new to the market, process innovations, and productivity. We use the simplified model in Fig. 1 below, which is akin to a knowledge production function but expands it on the right-hand side. The final target for most firms will be to survive and to achieve some kind of growth, which could be an increase in size of the firm, increased profits, or a combination. Data for these variables are not only more difficult to select, especially in the time dimension, but the number of confounding variables is also large. We therefore stick with the middle section of the model, where knowledge is transformed into innovations and thus leads to a possible growth in productivity.

Among our dependent variables, we pay particular attention to service innovations. As stated above, we believe knowledge of services is easier to transfer through employees than knowledge that relates to tangible goods. This goes both for service sectors and for service innovations as a dependent. The CIS questionnaire, which we will use for our analysis, asks firms whether they introduced services that were new to the firm,

\footnotetext{
2 The CIS questionnaire distinguishes between "new or significantly improved goods" and "new or significantly improved services". The exact interpretation of these categories is left to the respondent, but examples are given of possible improvements: "such as improved software, user friendliness, components, or sub-systems." (These are the texts of the official English version; the Dutch version contains a translation of this text.)
} 

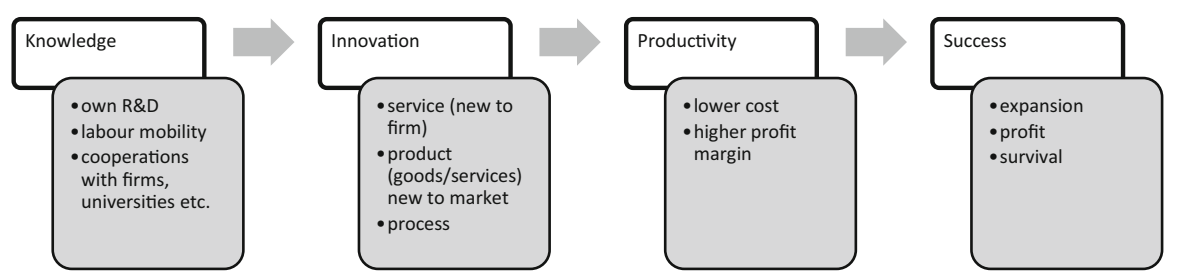

Fig. 1 A simple model

not necessarily to the market as a whole. In other words, the questionnaire asked after the adoption of innovations developed elsewhere. ${ }^{3}$ Since innovations at the firm level are easier to achieve than innovations that are new to the market as a whole, we expect the highest positive effect of labour mobility for this dependent variable.

We then turn to innovations that are new to the market as a whole, which will allow us to study the effect new inputs can have on the possibilities of recombination. This covers both services and goods; the CIS questionnaire does not allow us to distinguish between the two types here. The third type of innovation, process innovations, can cover all kinds of technical levels, and in this respect, they serve as a background check. Unfortunately, it is difficult to estimate what a firm is really doing; theoretically, a firm could replace one machine in a chain of fifty, or open a completely new chain, and in both cases, the same box would be ticked on the questionnaire.

Finally, we look at productivity, which is a measurement of firm success further down the line (see Fig. 1): inventions lead to innovations, which can lead to an increase in production, and these are translated into higher productivity per employee-but not necessarily so, as shown by Freel and Robson (2004). As discussed above, we will run separate regressions by size class and broad sector, to check possible underlying heterogeneity in these respects. Since productivity increases are often linked to innovation (Brusoni et al. 2006), we include process innovations as an explanatory variable in the analysis of productivity.

As our dependent variable of firm-level productivity, we use total factor productivity data generously provided by Möhlmann (2013). He used the firm-level Productivity Statistics from Statistics Netherlands to apply the Levinsohn and Petrin (2003) method. With this method, the inputs and outputs of each firm are compared, which results in a firm-specific residual. These numbers are then standardized by sector; a value of -1 thus represents a firm whose productivity is one standard deviation below its sectoral average. $^{4}$

\footnotetext{
${ }^{3}$ Strictly speaking, the wording and organization of the questionnaire imply innovations new to the market are also included in this number, since they are by definition also new to the firm.

${ }^{4}$ See Möhlmann (2013) for further details. The actual raw numbers for each firm are of course strictly confidential.
} 


\subsection{Variables of interest}

The key inputs in the simple model above are three types of knowledge: firstly, that produced by the firm itself; secondly, knowledge gained through acquiring new employees; and finally, other external knowledge, that is accessed, for example through cooperations with other firms or with universities. For the first, we include the R\&D efforts of the firm; for the last, we use self-reported data on whether a firm collaborates, as well as generic 'black-box' agglomeration variables.

In this paper, we concentrate on the second type: the new employees. In our opinion, four aspects are important for knowledge transfusion through human capital, i.e. the hiring of new employees from other firms. Since the bearers of this knowledge are the workers, these relevant aspects are their number, their individual value ${ }^{5}$, whether they come from the same sector or not, and, as discussed above, their diversity of sources - to how many distinct firms do they give access.

The first characteristic of new employees is the bare fact that they are fresh people, who are less accustomed to the routines of their new employer-and thus they will provide the variety of ideas needed to prevent lock-in. For the sectoral dimension, the effect can go both ways, akin to the debate on related variety (Frenken et al. 2007): some amount of variety helps to prevent lock-in, but too much variety means cognitive distances become too large for meaningful communication.

As for the wage of employees, our hypothesis is that the effect of the better-paid employees will be larger than that for others. Higher educated staff has a beneficial effect in general on firm success, as one would expect, although a recent meta-analysis showed that the knowledge and skills are more important than education and experience (Unger et al. 2011). If human capital indeed is the carrier of knowledge between firms, attracting employees with a higher capital value will mean more knowledge. This variable is therefore related to those previous studies where only R\&D employees are filtered out; such a filter makes sense when looking at patents or perhaps innovations, but does restrict the set of firms to be analysed to those actively pursuing R\&D.

In summary, for each firm, we calculate for the years 2000 and 2004 (with the variable name in italics):

- the number of employees who enter the firm (arrivals);

- the diversity of arrivals, i.e. the spread of these employees over different originating firms;

- the number of highly paid arrivals, selected as those within the top 25\% of the daily wage (an average of $€ 193$ ) - which is our best proxy for education and skills. This effect is additional to the general effect of the first variable;

\footnotetext{
5 This could be their productivity, education, or skills; we will proxy these by using their wage at the donor firm. Comprehensive education data are a weak point in Dutch microdata, and using the subsample for which such data are available would lower the number of observations too drastically. Likewise, skill data, as Boschma et al. (2009) use for Sweden, is not available for the full population. However, wages are available for almost all employees, and we use these as a proxy for the 'usefulness' of employees. Other factors, such as age (Schubert and Andersson 2015), are available, but would complicate the model to such an extent that they are better covered in separate analyses. See Groot et al. (2014) for the relation between wage and various variables at the regional and individual level.
} 
- the diversity of highly paid arrivals;

- and the number of arrivals from the same sector, where the sector is defined at the 3-digit level. ${ }^{6}$ This will capture the added effect of employees who will have some cognitive proximity to their new host (Boschma 2005).

We also attempted to further specify the relevant channels by looking at characteristics of the originating firms. We modelled the total number of previously innovative firms a firm is in contact with, as well as the total inputs in knowledge production processes that a firm can potentially 'tap into' through employee linkages, including contacts with other firms that have completed innovations, or have started innovations but have not managed to complete them yet; contacts with other firms that use different kinds of inputs into the knowledge production process, whether that be intramural R\&D or outsourced R\&D; and contacts with firms that are themselves parts of networks or cooperations. However, such analyses led to a confusing amount of variables, almost none of which were statistically significant, ${ }^{7}$ and many of which had unexpected signs. $^{8}$

\subsection{Endogeneity}

There is a risk of endogeneity when studying innovation and the influx of new employees. More successful firms will be able to hire better, more expensive staff. We do not believe this is a risk in our innovation analyses based on the CIS, for two reasons related to timing. Firstly, translating an innovation into profits, productivity growth, and firm growth takes time, even in a setting of continuous innovation (Boer and Gertsen 2003). Secondly, an innovation in 2004 can only influence the hiring of a new employee in 2001 in the sense that an employee is hired in order to contribute-and that would in fact be the effect we're looking for. This also goes for poaching behaviour, where firms know of specific knowledge employees supposedly carry (e.g. Reinau 2011). A conscious strategy on the part of a firm to use new human capital for innovations is simply one way to arrive at the possible benefit of labour mobility, indistinguishable from the effect of employees hired for other reasons. ${ }^{9}$ On the whole we therefore believe it is safe to interpret the relationships found as causalities, where innovation is concerned. Note, however, that the diversity of employees will not be very sensitive to these issues at all.

\footnotetext{
6 Arrivals from the same sector could be measured at different levels of similarity. However, we found that using the 2-digit level instead of the 3-digit level leads to extremely similar results. These results are available upon request. An analysis at the 5-digit level, to conform with Kronenberg and Carree (2010a), was not possible because it would restrict the number of observations too much.

7 Quite possibly spuriously, since at we would expect some false positives.

8 Results for such an analysis for the innovation analyses are available upon request.

9 Because the innovation counter starts at zero every new CIS round, a firm has to innovate again in order to be earmarked as an innovator. On the other hand, we should note that strictly speaking, firms were asked in CIS4 whether they innovated in the 2002-2004 period, so there is some overlap with the hiring of new employees between 2000 and 2004, and it is theoretically possible the innovation took place straight away in 2002, resulted in profits, allowed the firm to grow fast, and thus led to an inflow of employees.
} 
For productivity, on the other hand, the risk is larger. The link between productivity, profits, and growth is much tighter. We have therefore performed an IV analysis, instrumenting the arrival of highly paid employees to each specific firm with the average in its sector (but relative to the size of the firm). Since our productivity variable is estimated as a firm-specific offset from the average productivity within the sector, using the sectoral labour mobility figures should be safe. ${ }^{10}$ Note that, as in Stoyanov and Zubanov (2012), our productivity measure already has taken capital investments into account and is thus a more pure measure than added value per employee.

\subsection{Control variables}

Firstly, we control for firm size; we will also run separate regressions for larger and smaller firms. In the analysis of productivity, we also have to include employment growth (Aghion and Howitt 1994) as an explanatory variable, since this is not only a possible indicator of firm success but could also directly influence productivity, viz. if employment goes down while total production stays the same. ${ }^{11}$

We then control for the ability of the firm to access other outside sources of knowledge, the so-called absorptive capacity of the firm. The absorptive capacity of firms, defined in a seminal paper by Cohen and Levinthal (1990, p. 569) as 'the ability to identify, assimilate, and exploit knowledge from the environment', determines how firms react to innovations developed within the firm and elsewhere, and how this knowledge is used in the development of future products and services. Although in its original form the concept focused on R\&D, it has been extended to incorporate organizational form, networks, management and communication processes, and the human capital of the workforce (Dyer and Singh 1998; Lane and Lubatkin 1998; Zahra and George 2002). In this paper, we take a broad view of absorptive capacity, and operationalize ${ }^{12}$ absorptive capacity using measures of human capital, R\&D, management and organizational form, and collaborative links, following Abreu et al. (2008). They define absorptive capacity as referring to 'the ability to assimilate and manage knowledge in order to improve innovation performance and comparative advantage'. The absorptive capacity as a whole thus moderates the influence new knowledge can have for a firm, and correcting for it is necessary.

We selected four available indicators from the CIS that are relevant for our study, following Smit et al. (2015). Firstly, we include a variable on training: a firm that actively

\footnotetext{
10 We thank one of our anonymous reviewers for this suggestion.

11 It should be noted that the data on the number of employees are reported by firms in the CIS questionnaire. However, these data diverge wildly from register data in some cases, at least for the Dutch CIS. We have therefore replaced these numbers with numbers from the registers of firms (ABR) and employees (SSB).

12 Note that 'absorptive capacity' is a very popular concept at the moment, and the term is loosely used in different contexts and for different purposes, as surveyed by Lane et al. (2006). They found many studies reify the concept, bending and redefining the concept for their own purposes. We do not endeavour to delve into or expand upon the concept, but neither do we aim to redefine it. We do note, however, that we see strong links with notions of human and technological capital. Lane et al. (2006, p. 838) indicate that Cohen and Levinthal themselves were not so clear about the concept themselves either; Cohen and Levinthal were especially unclear in distinguishing whether we should see absorptive capacity as static property or as a dynamic process.
} 
advances the education of its employees, in the spirit of 'life-long learning', will have more up-to-date 'feelers' (i.e. its employees) out for new knowledge. Secondly, management is important: changes in the management techniques and organizational structures of a firm could indicate a flexible and adaptive firm culture, which would favour knowledge transfer and application. Thirdly, we would like to know something about the networks in which a firm is located; in the absence of such data, we use a variable on collaborations. Cooperating directly with higher education institutions, consultants and government agencies give access to knowledge. Although cooperations with other firms are also included, cooperations between two firms would involve the voluntary sharing of knowledge, whereas employees can also 'export' tacit knowledge the firm would rather have kept inside. ${ }^{13}$ Finally, we include variables on market scope. A firm involved in international markets may be under greater pressure to innovate; at the same time, international contacts might encourage and aid innovation. We will be able to distinguish firms that operate only within the Netherlands (the reference category) from firms that operate only outside the Netherlands and firms that operate both inside and outside the country. Moreover, we will also include a variable that indicates a firm is involved in new marketing strategies.

While the absorptive capacity of the firm measures its ability to deal with outside knowledge, we of course also control for one of the key sources of such knowledge: agglomeration economies. We include these based on the well-known model of Glaeser et al. (1992), who distinguished three main categories: local concentration, ${ }^{14}$ competition, and diversity (cf. its discussion above). Concentration, competition, and the variety of sectors present in one location can then be coupled, as Glaeser et al. (1992) did, to three main theories, where the so-called Marshall-Arrow-Romer effects are a combination of concentration with an absence of competition and variety; Porter effects are a combination of concentration with competition, i.e. a dominant role for smaller firms; and Jacobs effects a combination of competition with diversity. There is no definite answer which of these three represents the true or the most beneficial agglomeration mechanism; in fact, in different contexts, and at different points in time, different effects are found. What is worse, studies published at different points in time also point at different directions, suggesting a certain amount of publication bias (de Groot et al. 2015). In order to test the role of these three concepts in explaining variation in innovation across firms, we chose three commonly used statistics (see Beaudry and Schiffauerova 2009). These are:

- For concentration: a location quotient; the share number of employees in a 3-digit sector in a region divided by the national share of the sector.

- For competition: the average firm size in a 3-digit sector in a region.

\footnotetext{
13 They could do so even with less tacit knowledge-but we will not touch upon industrial espionage here.

14 The concept of concentration is closely related to specialization, but it takes the industry as its focus, instead of the region: a region specializing in one sector can in fact contain only a small part of nationwide activities in that sector (if the region is small enough), and a highly concentrated sector can be very small within the city (if the sector is small enough). An example of the first is agriculture in a small rural community; an example of the latter the diamond industry in Amsterdam. Many studies in the Glaeser-like literature mix concentration and specialization at random, without properly differentiating between the two.
} 
- For variety: a Hirschman-Herfindahl index on 3-digit sectoral shares within a region and Pavitt sector. ${ }^{15}$

Higher values on the competition variable indicate a lack of competition. Likewise, the variety or diversity measure has low values for more diversity. In the Netherlands, The Hague and some of the rural areas in the north-east have the highest values for our variety (or diversity) variable and hence the lowest diversity; industrial areas, such as those around Eindhoven in the southeast, have the highest values for variety. One important reason for this is the granularity of the sectoral classification used: the sectoral classification used by Statistics Netherlands up to 2008 (SBI '93) contains many more industrial sectors than service sectors. We choose to measure diversity within the Pavitt sectors, in order to incorporate findings from the so-called 'related variety' literature (Frenken et al. 2007; van Oort et al. 2015), which points out that there may well be benefits from locating near completely different firms, yet knowledge spillovers and recombinations will more easily be achieved between firms that share at least some knowledge base.

Alongside these agglomeration variables, many studies point at the importance of urbanization, by which we mean the non-sectoral clustering of people and firms. Here, the effect found in the literature is more consistently positive, though small (Melo et al. 2009). We control for urbanization using address densities; Statistics Netherlands provides these data based on both household and firm addresses, and it is therefore a slight improvement over traditional population density. Since the Netherlands as a whole presents a rather urbanized landscape, this variable will mainly capture the possible benefits of downtown location. We do so non-linearly, by using five classes. Finally, regional dummies cover remaining locational advantages, which might include a location closer to neighbouring countries, a harbour, better intraregional infrastructure, or regional cultural factors.

Since the innovation analyses have a dummy as the dependent variable, we estimate a probit model for these; firm-level productivity is estimated using common OLS as well as using instrumental variables, as discussed above. The next section describes the data sources, and it is followed by empirical results in Sect. 5.

\section{Data}

Since the days the influential Breschi and Lissoni (2001) paper was published, more and more microdata has become available, and employer-employee data can now be linked in many countries. We will use Dutch data here, from Statistics Netherlands. They offer a data set on all firms in the country (the Algemeen Bedrijvenregister or General Registry of Firms) and one on all jobs (the Sociaal-Statistisch Bestand or Social Statistics). We combine those with the Third and Fourth rounds of the Community Innovation Survey (CIS3, covering 1998-2000 and CIS4, covering 2002-2004). In the Netherlands, this survey is collected by Statistics Netherlands (CBS) within an EU-wide framework. Rather, similar questionnaires are undertaken in other countries,

\footnotetext{
15 Sector codes are generally seen as a useful and readily available tool to distinguish activities. Note, however, that some studies use patent classes instead (Rosenkopf and Almeida 2003; Song et al. 2003).
} 
Table 2 Size of firms in the data, compared to the firm population as of 1/1/2004 according to CBS Statline

\begin{tabular}{lcccc}
\hline Size class & Sample & Share of sample $(\%)$ & Population & Share of population $(\%)$ \\
\hline $10-49$ & 4411 & 50 & 53,115 & 8 \\
$50-249$ & 3587 & 40 & 11,055 & 32 \\
$250-499$ & 486 & 5 & 1410 & 34 \\
$500-999$ & 260 & 3 & 745 & 35 \\
$1000+$ & 165 & 2 & 605 & 27 \\
\hline
\end{tabular}

such as Canada, the USA, and Australia, with questions or answer options differing only to a small degree between participating countries.

In the Netherlands, a 10\% sample of firms with less than 100 employees received a questionnaire. Among firms with more than 100 employees, a census has been taken, and they have all received a questionnaire. The total response rate for CIS4 is about $70 \%$. Table 2 below lists the number of firms by size class in the data set.

Through the Social Statistics database, we have information on all employees in the Netherlands. Using this database, we match the firms which participated in CIS4 to their employees in 2004, and then extract from the database the firms where these employees worked in 2000. Assuming the CIS3 forms an unbiased sample for our purposes, we can now construct a pool of source firms where every firm in CIS4 is connected to. We remove all firms that have no connections whatsoever, leaving us with 6862 firms (out of around ten thousand observations in CIS4).

From these, we made a number of other corrections to remove unwanted effects. Firstly, we dropped all temp agencies and holdings, and we took out all employees who held more than five jobs in 2004. These two steps removed about 270,000 employees. Secondly, for 100,000 employees, no wage data were available, and we had to drop these as well. Finally, takeovers and mergers could bias our results; hence, we dropped all firms where $50 \%$ or more of the employees leave, which removes about 350,000 employees. In the resulting data set, we have about 2.3 million employees. An average of $4.7 \%$ of these employees has left the 'donor' firms; on the other side, the median number of employees received is 341 , but only 63 for the highly paid employees. Full descriptives and correlation tables can be found in the Appendix, Tables 12 and 13 .

For our regional agglomeration variables, we have used the General Business Register (ABR), which is a census, covering all establishments, so we do not have to worry about an uneven regional distribution. We calculate these at the NUTS3 level, the Dutch Corop regions. The Netherlands has 40 COROP regions, which approximate labour market regions, with the restriction that they do not cross provincial boundaries. Because of this approximation, the lack of arguments for other regional shapes, and the importance of institutions, we prefer such fixed regions over self-constructed regions, based on the microdata. We should keep in mind that the 40 regions we chose to employ are quite large; some of them measure $50 \mathrm{~km}$ across, corresponding on average to half an hour driving time from edge 
Table 3 Pavitt sectors

\begin{tabular}{lllllll}
\hline Pavitt sector & \multicolumn{2}{c}{ Concentration Competition } & $\begin{array}{l}\text { Service } \\
\text { innovation } \\
\text { \% innovating }\end{array}$ & $\begin{array}{l}\text { Products new } \\
\text { to market } \\
\text { \% innovating }\end{array}$ & $\begin{array}{l}\text { Process } \\
\text { innovation } \\
\text { \% innovating }\end{array}$ & $\begin{array}{l}\text { Productivity } \\
\text { Levinsohn } \\
\text { and Petrin }\end{array}$ \\
\hline $\begin{array}{c}\text { Science-based } \\
\text { Specialized }\end{array}$ & 2.70 & 0.30 & 0.08 & 0.33 & 0.43 & 0.46 \\
$\begin{array}{c}\text { suppliers } \\
\text { Scale-intensive }\end{array}$ & 1.63 & 0.25 & 0.15 & 0.37 & 0.37 & 0.15 \\
$\begin{array}{c}\text { Supplier- } \\
\text { dominated }\end{array}$ & 2.21 & 0.09 & 0.09 & 0.12 & 0.22 & 0.18 \\
$\begin{array}{c}\text { Knowledge- } \\
\text { intensive } \\
\text { business } \\
\text { sectors (KIBS) }\end{array}$ & 1.19 & 0.06 & 0.18 & 0.17 & 0.31 & 0.18 \\
$\begin{array}{c}\text { Traditional } \\
\text { services }\end{array}$ & 1.18 & 0.03 & 0.08 & 0.18 & 0.26 & 0.14 \\
\hline
\end{tabular}

to centre. Our results on agglomeration are therefore only valid for this specific scale.

Since we do not believe all types of firms enjoy agglomeration effects to a similar degree, we choose to compute the agglomeration effects with 3-digit SBI sectors as the 'home' sector (e.g. for the location quotient), and to interact the resulting variables with 8 broad 'sectors' according to the classification devised by Keith Pavitt (Pavitt 1984), which is also used in Abreu et al. (2008), Smit and de Groot (2013), and as dummies in studies like Vinding (2006) and Cainelli and Iacobucci (2012). ${ }^{16}$ This classification has the advantage that it groups technologically similar industries, cutting across traditional, product-defined sectors. We thus allow for sectoral heterogeneity of agglomeration externalities, without resorting to general nonlinearity (Kleinknecht and Verspagen 1989; Vinding 2006). These sectors, with later additions on the service sector by Evangelista (2000), are given in Table 3, with the averages for the specialization and competition variables, as well as innovation rates and productivity. ${ }^{17}$

To control for urbanization effects, we also include an urbanization variable, provided by Statistics Netherlands, based on address density per $\mathrm{km}^{2}$; this includes both households and firms. We use five classes for this variable in five classes, as discussed above. The intuition is that core regions will have an advantage over the periphery, but where exactly the boundary between cores and peripheries lies in the Netherlands has never been conclusively established. The data we use for this variable are for 2003 . Figure 2 shows urbanization according to these five classes in the central Randstad.

\footnotetext{
16 Although Pavitt's definition is now over 20 years old, similar groupings are still developing. An example is the four categories devised by Leiponen and Drejer 2007, who distinguished science-based, marketdriven, production-intensive and supplier-dominated companies in Finland and Denmark. Archibugi 2001 provides an extensive discussion of the classification and its popularity.

17 Both Primary and Information Intensive industries are lacking in our data set.
} 


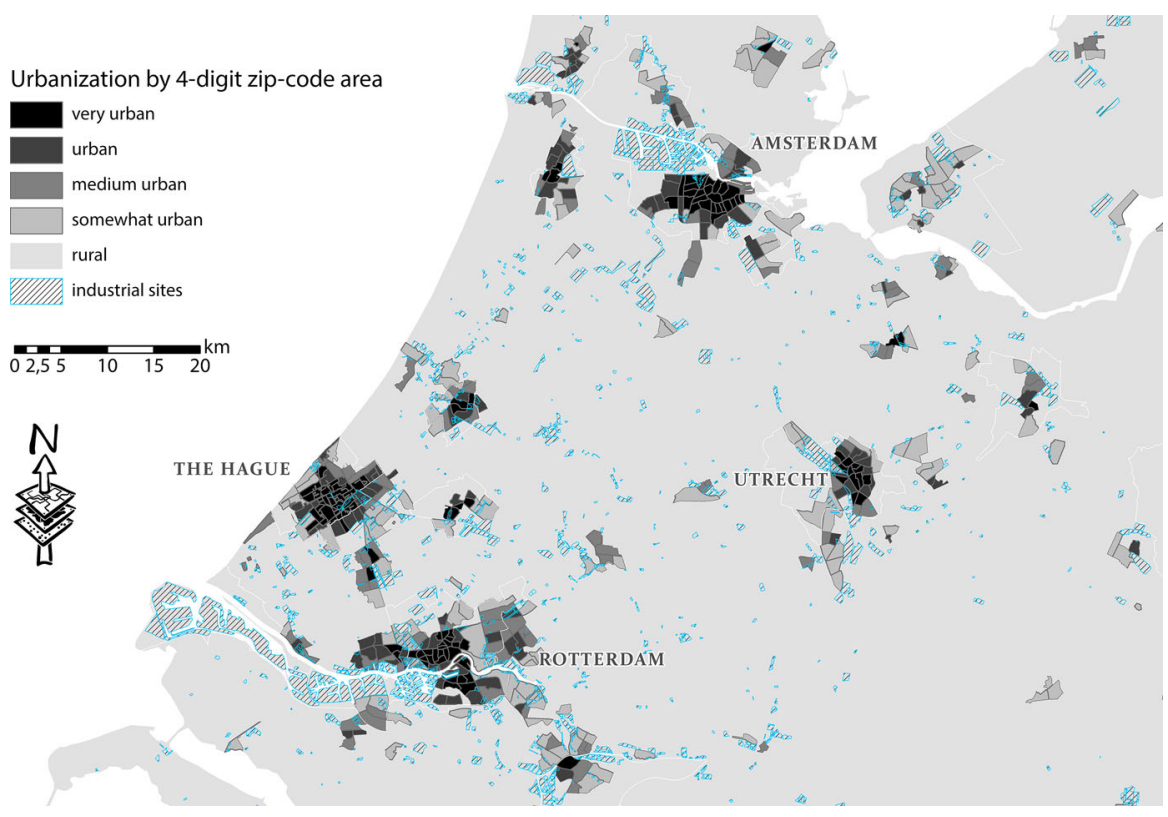

Fig. 2 Urbanization in the Randstad area, in five classes (definition: Statistics Netherlands, map by the author)

Note that the most rural class covers most of the countryside, and the other four classes cover different parts of the urban areas.

\section{Results}

In our first three models, we run a probit regression on the question whether a firm has innovated during the CIS4 period. Model (1) focuses on service innovations new to the firm; model (2) on innovations that are new to the market, and model (3) on process innovations. Since these are probit estimations, we look in particular at the marginal effects. Model (4) captures the effects on productivity, which we also split by size classes in model ( $5 \mathrm{a}-\mathrm{c})$, and by Pavitt sector in model (6).

Results are given in Tables 4, 5, and 6. At the top of each table, controls at the firm and at the regional level are reported. Our variables of interest can be found at the bottom. Note that due to the high correlation between the total number of arrivals and the number of highly paid arrivals $(r=0.84)$, we were constrained not to include the former. ${ }^{18}$ We discuss first the variables of interest, followed by a discussion of robustness and underlying heterogeneity, which is accompanied by Tables 7, 8. Finally, we discuss separately the results for the firm and regional variables.

\footnotetext{
18 We estimated its coefficient separately in a version of each model with only the diversity of employees from the set of labour mobility variables. Coefficients and $t$ values were 1: $0.000(0.34), 2: 0.000$ (1.32), 3: 0.000041 (4.11), 4: 0.004 (4.08). The last result is found in Table 11.
} 
Table 4 Regression results for service innovations and products new to the market

\begin{tabular}{|c|c|c|c|c|c|c|c|c|}
\hline \multirow[b]{2}{*}{ R\&D expenditure } & \multicolumn{2}{|l|}{$\begin{array}{l}\text { (1, probit) } \\
\text { Service } \\
\text { innovation } \\
\text { new to firm }\end{array}$} & \multicolumn{2}{|c|}{$\begin{array}{l}\text { (1, marginal } \\
\text { effects) } \\
\text { Service } \\
\text { innovation } \\
\text { new to firm }\end{array}$} & \multicolumn{2}{|c|}{$\begin{array}{l}\text { (2, probit) } \\
\text { Product } \\
\text { innovation } \\
\text { new to market }\end{array}$} & \multicolumn{2}{|c|}{$\begin{array}{l}\text { (2, marginal } \\
\text { effects) } \\
\text { Product } \\
\text { innovation } \\
\text { new to market }\end{array}$} \\
\hline & $0.157^{* * *}$ & (11.67) & $0.021^{* * *}$ & (11.79) & $0.213^{* * *}$ & $(16.72)$ & $0.030^{* * *}$ & (17.15) \\
\hline R\&D staff & $-0.242^{* * *}$ & $(-8.86)$ & $-0.032^{* * *}$ & $(-8.91)$ & $-0.180^{* * *}$ & $(-6.80)$ & $-0.025^{* * *}$ & $(-6.81)$ \\
\hline $\begin{array}{l}\text { Small firm } \\
(10-49)^{*}\end{array}$ & Ref.cat. & & Ref.cat. & & Ref.cat. & & Ref.cat. & \\
\hline $\begin{array}{l}\text { Medium firm } \\
(50-249)^{*}\end{array}$ & $-0.163^{* *}$ & $(-3.11)$ & $-0.021^{* *}$ & $(-3.12)$ & $-0.113^{*}$ & $(-2.23)$ & $-0.016^{*}$ & $(-2.24)$ \\
\hline $\begin{array}{l}\text { Larger firm } \\
\qquad(250-499)^{*}\end{array}$ & 0.007 & $(0.07)$ & 0.001 & $(0.07)$ & -0.054 & $(-0.60)$ & -0.008 & $(-0.61)$ \\
\hline $\begin{array}{l}\text { Very large firm } \\
(500-999)^{*}\end{array}$ & 0.073 & $(0.63)$ & 0.011 & $(0.61)$ & $-0.308^{*}$ & $(-2.44)$ & $-0.040^{* *}$ & $(-2.69)$ \\
\hline $\begin{array}{l}\text { Superlarge firm } \\
(1000+)^{*}\end{array}$ & 0.029 & $(0.17)$ & 0.004 & $(0.17)$ & -0.339 & $(-1.89)$ & $-0.044^{*}$ & $(-2.11)$ \\
\hline $\begin{array}{l}\text { Firm engages in } \\
\text { training* }\end{array}$ & $0.707^{* * *}$ & (14.02) & $0.095^{* * *}$ & $(14.26)$ & $0.564^{* * *}$ & $(11.51)$ & $0.079^{* * *}$ & (11.65) \\
\hline $\begin{array}{l}\text { New mngmt } \\
\text { techniques* }\end{array}$ & $0.151^{* *}$ & $(2.81)$ & $0.020^{* *}$ & $(2.81)$ & 0.073 & $(1.33)$ & 0.010 & (1.33) \\
\hline $\begin{array}{l}\text { New org. } \\
\text { structures* }\end{array}$ & $0.150^{* *}$ & $(2.98)$ & $0.020^{* *}$ & $(2.98)$ & 0.081 & (1.62) & 0.011 & (1.62) \\
\hline $\begin{array}{c}\text { New marketing } \\
\text { strategies* }\end{array}$ & $0.605^{* * *}$ & $(9.45)$ & $0.081^{* * *}$ & $(9.51)$ & $0.289^{* * *}$ & $(4.35)$ & $0.041^{* * *}$ & $(4.36)$ \\
\hline $\begin{array}{l}\text { Firm collaborates } \\
\text { on innov.* }\end{array}$ & $0.662^{* * *}$ & $(12.57)$ & $0.089^{* * *}$ & (12.78) & $0.611^{* * *}$ & (12.14) & $0.086^{* * *}$ & (12.37) \\
\hline $\begin{array}{l}\text { Firm receives govt } \\
\text { support* }\end{array}$ & -0.011 & $(-0.17)$ & -0.001 & $(-0.17)$ & $0.547^{* * *}$ & $(9.45)$ & $0.077^{* * *}$ & $(9.56)$ \\
\hline $\begin{array}{l}\text { Markets nat. + } \\
\text { internat.* }\end{array}$ & -0.054 & $(-1.13)$ & -0.007 & $(-1.13)$ & $0.250^{* * *}$ & $(5.40)$ & $0.035^{* * *}$ & $(5.40)$ \\
\hline $\begin{array}{l}\text { Markets only } \\
\text { international* }\end{array}$ & -0.127 & $(-1.14)$ & -0.017 & $(-1.14)$ & 0.154 & $(1.54)$ & 0.022 & $(1.54)$ \\
\hline $\begin{array}{l}\text { Concentration (all } \\
\text { sectors) }\end{array}$ & & & 0.001 & $(0.22)$ & & & 0.004 & $(1.58)$ \\
\hline $\begin{array}{l}\text { Conc (science } \\
\text { based) }\end{array}$ & -0.034 & $(-1.29)$ & & & -0.027 & $(-1.03)$ & & \\
\hline $\begin{array}{l}\text { Conc (spec. } \\
\text { suppliers) }\end{array}$ & -0.016 & $(-0.64)$ & & & -0.042 & $(-1.84)$ & & \\
\hline $\begin{array}{l}\text { Conc } \\
\text { (scale-intensive) }\end{array}$ & 0.007 & $(0.72)$ & & & 0.002 & $(0.24)$ & & \\
\hline $\begin{array}{l}\text { Conc (supplier- } \\
\text { dominated) }\end{array}$ & -0.050 & $(-1.78)$ & & & -0.038 & $(-1.67)$ & & \\
\hline
\end{tabular}


Table 4 continued

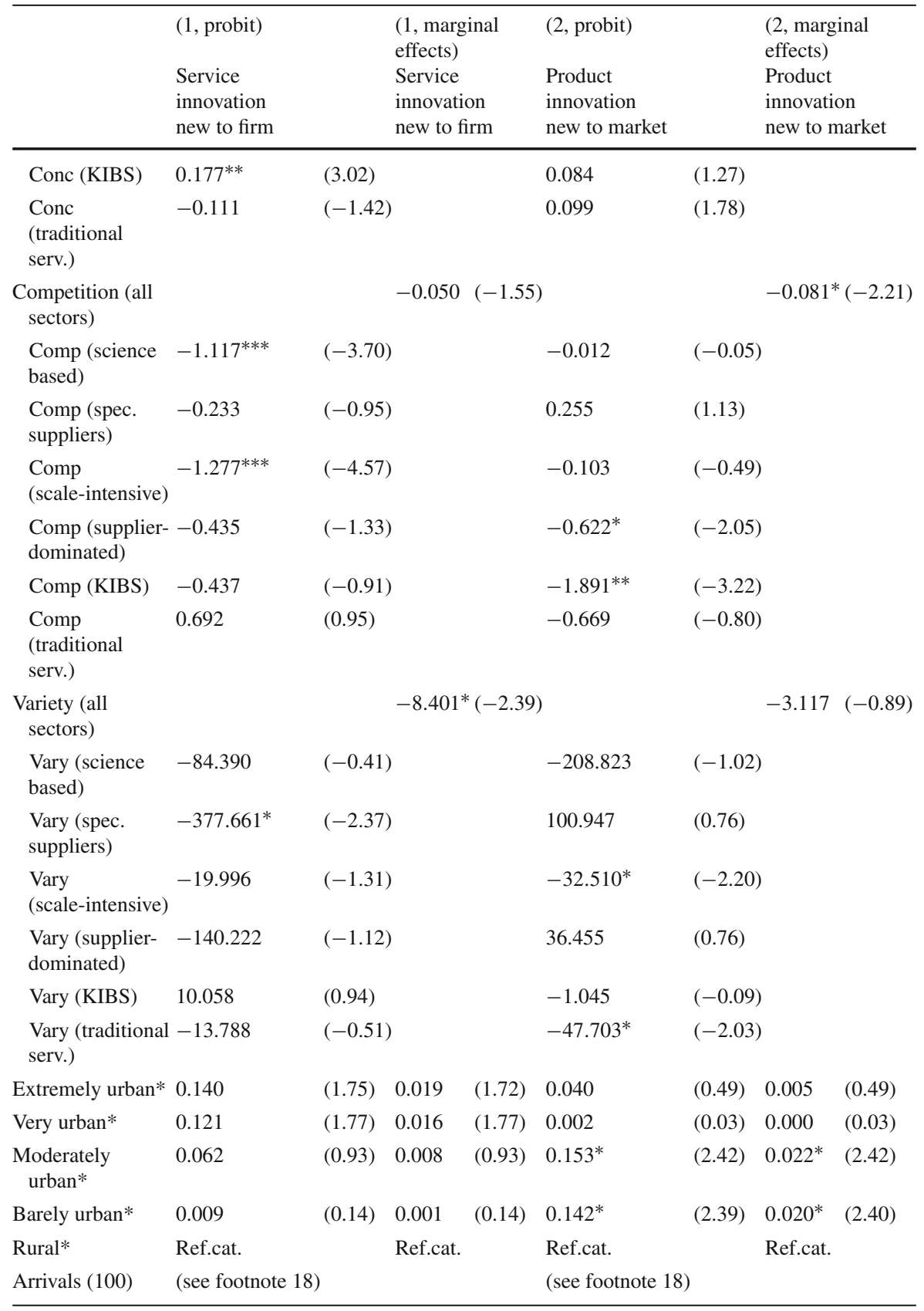


Table 4 continued

\begin{tabular}{|c|c|c|c|c|c|c|c|c|}
\hline \multirow[b]{2}{*}{$\begin{array}{l}\text { Diversity of } \\
\text { arrivals }\end{array}$} & \multicolumn{2}{|l|}{$\begin{array}{l}\text { (1, probit) } \\
\text { Service } \\
\text { innovation } \\
\text { new to firm }\end{array}$} & \multicolumn{2}{|c|}{$\begin{array}{l}\text { (1, marginal } \\
\text { effects) } \\
\text { Service } \\
\text { innovation } \\
\text { new to firm }\end{array}$} & \multicolumn{2}{|c|}{$\begin{array}{l}\text { (2, probit) } \\
\text { Product } \\
\text { innovation } \\
\text { new to market }\end{array}$} & \multicolumn{2}{|c|}{$\begin{array}{l}\text { ( } 2 \text {, marginal } \\
\text { effects) } \\
\text { Product } \\
\text { innovation } \\
\text { new to market }\end{array}$} \\
\hline & -0.562 & $(-1.66)$ & -0.075 & $(-1.66)$ & -0.296 & $(-0.91)$ & -0.042 & $(-0.91)$ \\
\hline $\begin{array}{l}\text { Highly paid } \\
\text { arrivals (100) }\end{array}$ & $0.046^{*}$ & $(2.05)$ & $0.006^{*}$ & $(2.05)$ & 0.038 & (1.63) & 0.005 & (1.63) \\
\hline $\begin{array}{l}\text { Diversity of } \\
\text { highly paid arr. }\end{array}$ & $-0.220^{*}$ & $(-2.08)$ & $-0.030^{*}$ & $(-2.08)$ & -0.065 & $(-0.66)$ & -0.009 & $(-0.66)$ \\
\hline $\begin{array}{l}\text { Arrivals from } \\
\text { same sector } \\
(100)\end{array}$ & 0.001 & $(0.13)$ & 0.000 & $(0.13)$ & 0.006 & $(0.55)$ & 0.001 & $(0.55)$ \\
\hline $\begin{array}{l}\text { Provincial } \\
\text { dummies }\end{array}$ & Yes & & Yes & & Yes & & Yes & \\
\hline Sectoral dummies & No & & Yes & & No & & Yes & \\
\hline Constant & $-1.898^{* * *}$ & $(-11.52)$ & n.a. & & $-1.779^{* * *}$ & $(-12.35)$ & n.a. & \\
\hline$N$ & 8909 & & & & 8909 & & & \\
\hline Pseudo $R^{2}$ & 0.302 & & & & 0.393 & & & \\
\hline
\end{tabular}

Variables marked with a * are dummy variables. For competition, variety, and diversity variables, high values indicate a low degree of the concept in question. Every second column gives $t$ statistics in parentheses; ${ }^{*} p<0.05,{ }^{* *} p<0.01,{ }^{* * *} p<0.001$. Probit models include a McFadden Pseudo $R^{2}$. Marginal effects for interaction effects can not be computed; therefore, the agglomeration variables are computed without interactions, and sectoral dummies are included separately. Hence, $t$ statistics differ slightly between the regular probit and the marginal effects

\subsection{Results for labour mobility}

Our first striking result is that the diversity of new employees has a positive and statistically significant impact on productivity - the coefficient is negative, but since the variable is a Hirschman-Herfindal, it measures the lack of diversity, and thus a negative coefficient indicates a positive effect of diversity. Diversity has a less significant but again positive result on service innovations new to the firm: the effect for high-paid workers is statistically significant at $1 \%$, but the marginal effect for diversity across all new employees is over twice as large, even though its standard error is so much higher that the associated $p$-value would be just under $10 \%$. However, the diversity of new employees does not matter for product innovations new to the market, even though this is traditionally the area where Schumpeterian Neue Kombinationen would be expected (Keijl et al. 2016).

Higher-paid workers that move can indeed promote service innovation and productivity growth; regular labour mobility only does so for process innovations and productivity, but with much lower coefficients (see footnote 19). The strongest effects are those linking new employees to a productivity increase, with more valuable employees producing an even stronger effect, but new employees also have a pos- 
Table 5 Regression results for process innovation

\begin{tabular}{|c|c|c|c|c|}
\hline \multirow[b]{2}{*}{ R\&D expenditure } & \multicolumn{2}{|c|}{$\begin{array}{l}\text { ( } 3 \text {, probit) } \\
\text { Process innovation }\end{array}$} & \multicolumn{2}{|c|}{$\begin{array}{l}\text { ( } 3, \text { marginal effects }) \\
\text { Process innovation }\end{array}$} \\
\hline & $0.191^{* * *}$ & $(15.01)$ & $0.034 * * *$ & $(15.40)$ \\
\hline R\&D staff & $-0.353^{* * *}$ & $(-12.84)$ & $-0.063^{* * *}$ & $(-13.05)$ \\
\hline Small firm (10-49)* & $0.000()$. & & $0.000()$. & \\
\hline Medium firm (50-249)* & -0.010 & $(-0.22)$ & -0.002 & $(-0.22)$ \\
\hline Larger firm $(250-499)^{*}$ & 0.079 & $(0.92)$ & 0.014 & $(0.90)$ \\
\hline Very large firm (500-999)* & $0.565^{* * *}$ & $(5.05)$ & $0.120^{* * *}$ & $(4.39)$ \\
\hline Superlarge firm $(1000+)^{*}$ & $0.358^{*}$ & $(2.20)$ & $0.071^{*}$ & $(1.99)$ \\
\hline Firm engages in training* & $1.136^{* * *}$ & $(24.05)$ & $0.201^{* * *}$ & $(25.64)$ \\
\hline New mngmt techniques* & $0.614^{* * *}$ & $(12.23)$ & $0.109^{* * *}$ & $(12.35)$ \\
\hline New org. structures* & $0.104^{*}$ & $(2.26)$ & $0.018^{*}$ & $(2.26)$ \\
\hline New marketing strategies* & $0.309^{* * *}$ & $(4.63)$ & $0.055^{* * *}$ & $(4.64)$ \\
\hline Firm collaborates on innov.* & $0.725^{* * *}$ & $(14.27)$ & $0.129^{* * *}$ & $(14.56)$ \\
\hline Firm receives govt support* & $0.274^{* * *}$ & $(4.53)$ & $0.049^{* * *}$ & $(4.54)$ \\
\hline Markets nat. + internat.* & 0.070 & $(1.69)$ & 0.012 & $(1.69)$ \\
\hline Markets only international* & 0.119 & $(1.34)$ & 0.021 & $(1.34)$ \\
\hline Concentration (all sectors) & & & 0.004 & $(1.11)$ \\
\hline Conc (science based) & -0.008 & $(-0.39)$ & & \\
\hline Conc (spec. suppliers) & -0.013 & $(-0.54)$ & & \\
\hline Conc (scale-intensive) & 0.022 & $(1.47)$ & & \\
\hline Conc (supplier-dominated) & 0.007 & $(0.36)$ & & \\
\hline Conc (KIBS) & -0.077 & $(-1.30)$ & & \\
\hline Conc (traditional serv.) & 0.099 & $(1.93)$ & & \\
\hline Competition (all sectors) & & & 0.027 & $(0.69)$ \\
\hline Comp (science based) & 0.018 & $(0.08)$ & & \\
\hline Comp (spec. suppliers) & -0.198 & $(-0.85)$ & & \\
\hline Comp (scale-intensive) & -0.102 & $(-0.49)$ & & \\
\hline Comp (supplier-dominated) & 0.344 & $(1.32)$ & & \\
\hline Comp (KIBS) & $1.043^{*}$ & $(2.45)$ & & \\
\hline Comp (traditional serv.) & -0.012 & $(-0.02)$ & & \\
\hline Variety (all sectors) & & & -6.149 & $(-1.85)$ \\
\hline Vary (science based) & -70.973 & $(-0.48)$ & & \\
\hline Vary (spec. suppliers) & -184.721 & $(-1.34)$ & & \\
\hline Vary (scale-intensive) & 7.042 & $(0.59)$ & & \\
\hline Vary (supplier-dominated) & 42.905 & $(1.00)$ & & \\
\hline Vary (KIBS) & -2.591 & $(-0.24)$ & & \\
\hline Vary (traditional serv.) & $-69.248^{* *}$ & $(-3.27)$ & & \\
\hline
\end{tabular}


Table 5 continued

\begin{tabular}{lllll}
\hline & \multicolumn{2}{l}{$\begin{array}{l}\text { (3, probit) } \\
\text { Process innovation }\end{array}$} & \multicolumn{2}{l}{$\begin{array}{l}\text { (3, marginal effects) } \\
\text { Process innovation }\end{array}$} \\
\hline Extremely urban* & -0.032 & $(-0.44)$ & -0.006 & $(-0.45)$ \\
Very urban* & -0.053 & $(-0.87)$ & -0.009 & $(-0.87)$ \\
Moderately urban* & -0.071 & $(-1.23)$ & -0.012 & $(-1.23)$ \\
Barely urban* & 0.068 & $(1.28)$ & 0.012 & $(1.29)$ \\
Rural* & Ref.cat. & & Ref.cat. & \\
Arrivals (100) & $($ see footnote 19$)$ & & & \\
Diversity of arrivals & -0.315 & $(-1.11)$ & -0.056 & $(-1.11)$ \\
Highly paid arrivals (100) & 0.005 & $(0.21)$ & 0.001 & $(0.21)$ \\
Diversity of highly paid arr. & 0.056 & $(0.67)$ & 0.010 & $(0.67)$ \\
Arrivals from same sector (100) & -0.016 & $(-1.67)$ & -0.003 & $(-1.67)$ \\
Provincial dummies & Yes & & Yes & \\
Sectoral dummies & No & & Yes & \\
Constant & $-1.585^{* * *}$ & $(-11.68)$ & n.a. & \\
$N$ & 8909 & & & \\
Pseudo $R^{2}$ & 0.406 & & & \\
\hline
\end{tabular}

Variables marked with a * are dummy variables. For competition, variety, and diversity variables, high values indicate a low degree of the concept in question. Every second column gives $t$ statistics in parentheses; ${ }^{*} p<0.05,{ }^{* *} p<0.01,{ }^{* * *} p<0.001$

itive impact on process innovation. We should note that for productivity (model 4), the IV estimation confirms OLS results across the board. Apparently, the damage due to endogeneity was limited.

\subsection{Heterogeneity}

We have already discussed with possible endogeneity above and will now focus on the consistency of the effect across sectors and firm size classes. It is likely any effect will display heterogeneity across different actors-in regional science, many individual stories disprove in Popperian fashion the ubiquitous validity of general 'laws'. ${ }^{19}$ Moreover, meta-analyses have also shown how and where exactly these variations take place. ${ }^{20}$ We discuss results by firm size and by sector, focusing on productivity as the dependent.

Large and small firms operate differently. Jane Jacobs firmly believed large firms were unable to produce 'new work', and rather resorted to acquiring new activities wholesale (Jacobs 1969, p. 74 ff.). Large firms will already contain a large amount of heterogeneous knowledge, and labour mobility will be in competition with other

\footnotetext{
19 For example, the $2 \%$ convergence in Abreu et al. (2005) and the 5\% elasticity of density discussed in Melo et al. (2009).

20 Besides the two analysis mentioned in the previous note, one can also think of de Groot et al. (2015).
} 
Table 6 OLS and IV regression results for productivity

\begin{tabular}{|c|c|c|c|c|}
\hline \multirow[b]{2}{*}{ Change in employment } & \multicolumn{2}{|l|}{$\begin{array}{l}(4, \text { OLS }) \\
\text { Productivity }\end{array}$} & \multicolumn{2}{|l|}{$\begin{array}{l}(4, \mathrm{IV}) \\
\text { Productivity }\end{array}$} \\
\hline & 0.000 & $(0.55)$ & 0.000 & $(0.58)$ \\
\hline Process innovator & 0.030 & $(1.70)$ & 0.030 & $(1.71)$ \\
\hline Products new to market & 0.026 & $(1.41)$ & 0.027 & $(1.43)$ \\
\hline Small firm $(10-49) *$ & Ref.cat. & & Ref.cat. & \\
\hline Medium firm (50-249)* & $0.246^{* * *}$ & $(15.79)$ & $0.247 * * *$ & $(15.87)$ \\
\hline Larger firm $(250-499)^{*}$ & $0.526^{* * *}$ & (18.94) & $0.528^{* * *}$ & (18.97) \\
\hline Very large firm (500-999)* & $0.694^{* * *}$ & (17.98) & $0.699^{* * *}$ & $(17.92)$ \\
\hline Superlarge firm $(1000+)^{*}$ & $0.904^{* * *}$ & $(15.57)$ & $0.919^{* * *}$ & (14.87) \\
\hline Firm engages in training* & 0.009 & $(0.47)$ & 0.010 & $(0.48)$ \\
\hline Markets nat. + internat. & $0.051^{* * *}$ & $(3.69)$ & $0.052^{* * *}$ & $(3.71)$ \\
\hline Markets only international & 0.045 & $(1.55)$ & 0.045 & $(1.57)$ \\
\hline Conc (science based) & $0.045^{* * *}$ & $(7.07)$ & $0.045^{* * *}$ & $(7.10)$ \\
\hline Conc (spec. suppliers) & -0.008 & $(-1.04)$ & -0.008 & $(-1.04)$ \\
\hline Conc (scale-intensive) & -0.005 & $(-1.51)$ & -0.005 & $(-1.44)$ \\
\hline Conc (supplier-dominated) & 0.010 & $(1.44)$ & 0.010 & $(1.45)$ \\
\hline Conc (KIBS) & -0.043 & $(-1.77)$ & -0.042 & $(-1.75)$ \\
\hline Conc (traditional serv.) & 0.020 & $(1.12)$ & 0.020 & $(1.12)$ \\
\hline Comp (science based) & $0.325^{* * *}$ & $(4.16)$ & $0.325^{* * *}$ & $(4.18)$ \\
\hline Comp (spec. suppliers) & 0.034 & $(0.47)$ & 0.034 & $(0.46)$ \\
\hline Comp (scale-intensive) & $0.141^{*}$ & $(2.03)$ & $0.141^{*}$ & $(2.03)$ \\
\hline Comp (supplier-dominated) & 0.101 & $(1.09)$ & 0.101 & $(1.09)$ \\
\hline Comp (KIBS) & -0.000 & $(-0.00)$ & 0.000 & $(0.00)$ \\
\hline Comp (traditional serv.) & $0.763^{* * *}$ & $(3.59)$ & $0.764^{* * *}$ & $(3.61)$ \\
\hline Vary (science based) & -29.689 & $(-0.78)$ & -29.683 & $(-0.78)$ \\
\hline Vary (spec. suppliers) & -14.321 & $(-0.30)$ & -13.652 & $(-0.29)$ \\
\hline Vary (scale-intensive) & 1.442 & $(0.35)$ & 1.401 & $(0.34)$ \\
\hline Vary (supplier-dominated) & 3.476 & $(0.23)$ & 3.510 & $(0.23)$ \\
\hline Vary (KIBS) & 2.900 & $(0.71)$ & 2.899 & $(0.72)$ \\
\hline Vary (traditional serv.) & 5.925 & $(0.83)$ & 5.919 & $(0.83)$ \\
\hline Extremely urban* & 0.029 & $(1.16)$ & 0.029 & $(1.17)$ \\
\hline Very urban* & 0.030 & $(1.45)$ & 0.030 & $(1.47)$ \\
\hline Moderately urban* & 0.012 & $(0.63)$ & 0.012 & $(0.64)$ \\
\hline Barely urban* & -0.018 & $(-1.01)$ & -0.018 & $(-1.02)$ \\
\hline Rural* & Ref.cat. & & & \\
\hline Diversity of arrivals & $-0.573 * * *$ & $(-5.06)$ & $-0.570 * * *$ & $(-5.05)$ \\
\hline Highly paid arrivals (100) & $0.036^{* * *}$ & $(4.41)$ & $0.032^{* *}$ & $(3.28)$ \\
\hline Diversity of highly paid arr. & $-0.192 * * *$ & $(-5.92)$ & $-0.192 * * *$ & $(-5.95)$ \\
\hline Arrivals from same sector (100) & 0.002 & $(0.61)$ & 0.003 & $(0.74)$ \\
\hline Provincial dummies & Yes & & Yes & \\
\hline
\end{tabular}


Table 6 continued

\begin{tabular}{lllll}
\hline & $(4$, OLS $)$ & & $(4$, IV $)$ \\
& Productivity & & Productivity & \\
\hline Sectoral dummies & No & & No & $(-0.95)$ \\
Constant & -0.043 & $(-0.93)$ & -0.044 & \\
$N$ & 5565 & & 5565 & \\
Adjusted $R^{2}$ & 0.282 & 0.282 & \\
\hline
\end{tabular}

Variables marked with a * are dummy variables. For competition, variety, and diversity variables, high values indicate a low degree of the concept in question. Every second column gives $t$ statistics in parentheses; ${ }^{*} p<0.05,{ }^{* *} p<0.01,{ }^{* * *} p<0.001$. In IV estimations, highly paid arrivals are instrumented with the sectoral average

sources of knowledge. For small firms, the opposite may hold. In the management literature, several studies have focused specifically on the spillovers from large firms to small firms, suggesting the smaller firms should be on the receiving end (e.g. Eeckhout and Jovanovic 2002). Indeed, small firms in our analysis benefit significantly from a diverse inflow of new employees. However, medium firms also benefit, but for them, it is the diversity of highly paid employees - supposedly with more specialist knowledge - that matters. ${ }^{21}$ For large employees, the coefficient for the latter variable is even higher, but so is the standard error, reflecting so much underlying variety (in life cycle or other characteristics) that the effect of diverse highly paid employees is no longer statistically significant.

However, deeper analysis across different types of firms reveals the effects on productivity are not consistent at all across different types of firms. Results are conveniently summarized in Table 9. The productivity of small firms (up to 50 employees) is positively affected by the diversity of new labour in general, but not by that of highly paid labour; for medium and large firms, it is the other way around. This is an important insight, alluded to but not empirically tested in related work (Kronenberg and Carree 2010b; Stoyanov and Zubanov 2012). Our key hypothesis that a variety of new employees is beneficial for productivity or innovation in general, is thus only partly true. Finally, smaller firms may have a higher basic probability to innovate, as confirmed by the dummy coefficients by firm size in Table 4-but not for process innovations in Table 5-and they have a larger increase in productivity due to labour mobility, as shown by the separate regressions $(5 \mathrm{a}-\mathrm{c})$ in Table 7.

Strikingly, the more specific knowledge that can be expected of employees within a 3-digit sector does not offer additional benefits to the innovation rate of a firm (contra Stoyanov and Zubanov 2012). If we frame the employee flows in the context of the specialization-versus-diversity debate (Beaudry and Schiffauerova 2009; van der Panne and van Beers 2006), this implies within-sector 'specialisation' effects are not important, compared to cross-sector 'diversity' effects. New input from different

\footnotetext{
21 Our analysis is on three static categories; of particular interest is of course the set of firms that grows from small to medium; such firms hire in particular young, less educated, possibly immigrant workers, perhaps preferring on-the-job training over previously acquired skills (Coad et al. 2014).
} 
Table 7 OLS and IV regression results for productivity, by size class

\begin{tabular}{|c|c|c|c|c|c|c|}
\hline & $(5 \mathrm{a}, \mathrm{OLS})$ & $(5 \mathrm{a}, \mathrm{IV})$ & $(5 \mathrm{~b}, \mathrm{OLS})$ & $(5 b, I V)$ & $(5 \mathrm{c}, \mathrm{OLS})$ & $(5 c, I V)$ \\
\hline & \multicolumn{2}{|c|}{$\begin{array}{l}\text { Productivity (small } \\
\text { firms, } 10-49 \mathrm{emp} .)\end{array}$} & \multicolumn{2}{|c|}{$\begin{array}{l}\text { Productivity (medium } \\
\text { firms, 50-249 emp.) }\end{array}$} & \multicolumn{2}{|c|}{$\begin{array}{l}\text { Productivity (firms } \\
\geq 250 \text { employees) }\end{array}$} \\
\hline Change in employment & 0.001 & 0.001 & 0.000 & $0.00029^{* *}$ & -0.000 & -0.000 \\
\hline Process innovator & $0.090^{* *}$ & $0.090^{* *}$ & -0.005 & -0.003 & -0.013 & -0.012 \\
\hline Products new to market & -0.018 & -0.018 & $0.051^{*}$ & $0.057^{*}$ & 0.037 & 0.035 \\
\hline Small firm $(10-49)^{*}$ & n.a. & n.a. & n.a. & n.a. & n.a. & n.a. \\
\hline Medium firm $(50-249) *$ & n.a. & n.a. & n.a. & n.a. & n.a. & n.a. \\
\hline Larger firm $(250-499)^{*}$ & n.a. & n.a. & n.a. & n.a. & Ref.cat. & $-0.312^{* * *}$ \\
\hline Very large firm (500-999)* & n.a. & n.a. & n.a. & n.a. & $0.149^{* *}$ & $-0.168^{*}$ \\
\hline Superlarge firm $(1000+)^{*}$ & n.a. & n.a. & n.a. & n.a. & $0.341^{* * *}$ & Ref.cat. \\
\hline Firm engages in training* & -0.076 & -0.075 & 0.046 & $0.050^{*}$ & -0.001 & -0.002 \\
\hline Markets nat. + internat. & $0.084^{* * *}$ & $0.085^{* * *}$ & $0.050^{* *}$ & $0.057^{* *}$ & -0.013 & -0.013 \\
\hline Markets only international & 0.021 & 0.021 & 0.058 & 0.066 & 0.111 & 0.111 \\
\hline Conc (science based) & 0.025 & 0.025 & $0.044^{* * *}$ & $0.050^{* * *}$ & 0.019 & 0.019 \\
\hline Conc (spec. suppliers) & -0.025 & -0.025 & 0.010 & 0.013 & -0.006 & -0.006 \\
\hline Conc (scale-intensive) & 0.001 & 0.001 & 0.008 & 0.008 & -0.006 & -0.007 \\
\hline Conc (supplier-dominated) & 0.011 & 0.011 & 0.011 & 0.013 & 0.007 & 0.008 \\
\hline Conc (KIBS) & 0.042 & 0.043 & -0.023 & -0.020 & $-0.186^{* *}$ & $-0.188^{* *}$ \\
\hline Conc (traditional serv.) & 0.011 & 0.011 & 0.017 & 0.019 & 0.018 & 0.018 \\
\hline Comp (science based) & $-0.313^{*}$ & $-0.313^{*}$ & $0.524^{* * *}$ & $0.539^{* * *}$ & $1.165^{* * *}$ & $1.165^{* * *}$ \\
\hline Comp (spec. suppliers) & 0.194 & 0.193 & -0.018 & -0.012 & -0.096 & -0.090 \\
\hline Comp (scale-intensive) & $0.281^{*}$ & $0.280^{*}$ & -0.050 & -0.014 & $0.461^{*}$ & $0.465^{* *}$ \\
\hline Comp (supplier-dominated) & -0.025 & -0.027 & 0.123 & 0.112 & 0.443 & 0.441 \\
\hline Comp (KIBS) & -0.024 & -0.021 & 0.020 & 0.014 & 0.336 & 0.337 \\
\hline Comp (traditional serv.) & -0.154 & -0.150 & $1.356^{* * *}$ & $1.380^{* * *}$ & 0.796 & 0.792 \\
\hline Vary (science based) & -27.964 & -27.594 & $-131.757^{* *}$ & $-142.467^{* *}$ & $334.218^{* * *}$ & $333.151^{* * *}$ \\
\hline Vary (spec. suppliers) & 70.387 & 70.277 & -94.256 & -81.864 & 96.569 & 92.961 \\
\hline Vary (scale-intensive) & 7.177 & 7.188 & 1.845 & 1.901 & $-31.227^{*}$ & $-30.756^{*}$ \\
\hline Vary (supplier-dominated) & -4.312 & -4.195 & 8.129 & 7.223 & 17.398 & 16.383 \\
\hline Vary (KIBS) & 8.330 & 8.418 & -5.228 & -4.487 & 3.073 & 2.914 \\
\hline Vary (traditional serv.) & 24.629 & 24.466 & -4.595 & -5.494 & 31.881 & 31.938 \\
\hline Extremely urban* & 0.033 & 0.033 & 0.017 & 0.018 & 0.098 & 0.097 \\
\hline Very urban* & 0.056 & 0.055 & 0.026 & 0.028 & 0.004 & 0.004 \\
\hline Moderately urban* & 0.048 & 0.048 & 0.026 & 0.028 & -0.076 & -0.076 \\
\hline Barely urban* & 0.019 & 0.019 & -0.045 & $-0.049^{*}$ & 0.084 & 0.086 \\
\hline Rural* & Ref.cat. & & Ref.cat. & & Ref.cat. & \\
\hline Diversity of arrivals & $-0.590^{* * *} *$ & $-0.594 * * *$ & 0.033 & 0.208 & 1.549 & 1.496 \\
\hline Highly paid arrivals (100) & $0.702 * * *$ & 0.629 & -0.016 & $-0.128 * * *$ & $0.038 * * *$ & $0.047 * * *$ \\
\hline Diversity of highly paid arr. & -0.062 & -0.067 & $-0.432 * * *$ & $-0.451 * * *$ & -1.671 & -1.686 \\
\hline
\end{tabular}


Table 7 continued

\begin{tabular}{|c|c|c|c|c|c|c|}
\hline & $(5 \mathrm{a}, \mathrm{OLS})$ & $(5 \mathrm{a}, \mathrm{IV})$ & $(5 \mathrm{~b}, \mathrm{OLS})$ & $(5 \mathrm{~b}, \mathrm{IV})$ & $(5 c$, OLS $)$ & $(5 c, I V)$ \\
\hline & \multicolumn{2}{|c|}{$\begin{array}{l}\text { Productivity (small } \\
\text { firms, 10-49 emp.) }\end{array}$} & \multicolumn{2}{|c|}{$\begin{array}{l}\text { Productivity (medium } \\
\text { firms, 50-249 emp.) }\end{array}$} & \multicolumn{2}{|c|}{$\begin{array}{l}\text { Productivity (firms } \\
\geq 250 \text { employees) }\end{array}$} \\
\hline $\begin{array}{l}\text { Arrivals from same } \\
\text { sector }(100)\end{array}$ & 0.042 & 0.049 & $0.059 * *$ & $0.130^{* * * *}$ & -0.001 & -0.002 \\
\hline Provincial dummies & Yes & Yes & Yes & Yes & Yes & Yes \\
\hline Sectoral dummies & No & No & No & No & No & No \\
\hline Constant & -0.135 & -0.130 & $0.213 * * *$ & $0.201 * * *$ & $0.605 * * *$ & $0.921 * * *$ \\
\hline$N$ & 1836 & 1836 & 3008 & 3008 & 721 & 721 \\
\hline Adjusted $R^{2}$ & 0.052 & 0.052 & 0.069 & 0.063 & 0.328 & 0.327 \\
\hline
\end{tabular}

Variables marked with a * are dummy variables. For competition, variety, and diversity variables, high values indicate a low degree of the concept in question. $T$ statistics are available upon request. ${ }^{*} p<$ $0.05,{ }^{* *} p<0.01,{ }^{* * *} p<0.001$. In IV estimations, highly paid arrivals are instrumented with the sectoral average.

companies is valued, no matter whether these companies are in the same line of business. The single exception lies with medium-sized firms (50-249 employees), whose productivity is positively impacted by same-sector labour mobility. Perhaps, this points to a growth strategy specific to firms of this size and perhaps to firms in a specific part of the life cycle (cf., for the case of agglomeration effects, Duranton and Puga 2001; Neffke et al. 2011).

Different sectors do not only use and produce different types of knowledge, they also have different ways of dealing with knowledge (Pavitt 1984; Evangelista 2000). Hence, also their routines of dealing with new knowledge will differ. One can therefore look at innovation and productivity across the economy as a whole, but it can be a useful and necessary exercise better to split out the effects, for example across the broad, knowledge-based Pavitt sectors. The transferability of knowledge through human capital, as opposed to codified knowledge, could well be higher in service sectors than in capital-intensive manufacturing activities (Pennings et al. 1998), and thus the effect of labour mobility more noticeable. ${ }^{22}$ However, empirical evidence is scarce in this field.

Table 9 shows that here too there is strong heterogeneity in the results. The number of new (highly paid) arrivals has a significantly positive or statistically insignificant but possibly positive impact for all six sectors, and the same goes for the diversity effect, which we discussed above. However, when we look at the coefficients in the regressions (6a-6f), we see they are not larger for the service industries in the two rightmost columns, suggesting the effect is not stronger in the service sector than in manufacturing sectors. One group, that of the supplier-dominated industries, does show benefits of flows within the same (3-digit) subsector. This class includes textile industries, wood and paper, as well as the generic category 'other manufacturing'.

\footnotetext{
22 Unfortunately, in their meta-analysis of human capital, Unger et al. (2011) chose not to distinguish between services and manufacturing.
} 
Table 8 Regression results for productivity, by Pavitt sector

\begin{tabular}{|c|c|c|c|c|c|c|}
\hline Productivity & $\begin{array}{l}(6 a, I V) \\
\text { science-based }\end{array}$ & $\begin{array}{l}(6 b, I V) \\
\text { specialized } \\
\text { suppliers }\end{array}$ & $\begin{array}{l}(6 c, I V) \\
\text { scale-intensive }\end{array}$ & $\begin{array}{l}(6 \mathrm{~d}, \mathrm{IV}) \\
\text { supplier- } \\
\text { dominated }\end{array}$ & $\begin{array}{l}(6 \mathrm{e}, \mathrm{IV}) \\
\text { KIBS }\end{array}$ & $\begin{array}{l}(6 \mathrm{f}, \mathrm{IV}) \\
\text { traditional } \\
\text { services }\end{array}$ \\
\hline $\begin{array}{l}\text { Change in } \\
\text { employment }\end{array}$ & -0.000 & -0.000 & 0.000 & 0.000 & 0.000 & -0.000 \\
\hline Process innovator & 0.067 & 0.045 & -0.010 & 0.029 & 0.037 & 0.017 \\
\hline $\begin{array}{l}\text { Products new to } \\
\text { market }\end{array}$ & -0.064 & 0.066 & 0.056 & 0.083 & -0.001 & -0.028 \\
\hline $\begin{array}{l}\text { Small firm } \\
(10-49)^{*}\end{array}$ & 0.000 & 0.000 & 0.000 & 0.000 & 0.000 & 0.000 \\
\hline $\begin{array}{l}\text { Medium firm } \\
(50-249)^{*}\end{array}$ & $0.515^{* * *}$ & $0.177^{* *}$ & $0.255^{* * *}$ & $0.324^{* * *}$ & $0.157^{* * *}$ & $0.176^{* * *}$ \\
\hline $\begin{array}{l}\text { Larger firm } \\
\qquad(250-499)^{*}\end{array}$ & $1.003^{* * *}$ & $0.217^{*}$ & $0.425^{* * *}$ & $0.701^{* * *}$ & $0.347^{* * *}$ & $0.470^{* * *}$ \\
\hline $\begin{array}{l}\text { Very large firm } \\
(500-999)^{*}\end{array}$ & $0.982^{* * *}$ & $0.367^{*}$ & $0.493^{* * *}$ & $0.791^{* * *}$ & $0.427^{* * *}$ & $0.674^{* * *}$ \\
\hline $\begin{array}{l}\text { Superlarge firm } \\
(1000+)^{*}\end{array}$ & 0.427 & 0.383 & $0.510^{* * *}$ & 0.911 & $0.492^{* * *}$ & $0.954^{* * *}$ \\
\hline $\begin{array}{l}\text { Firm engages in } \\
\text { training* }\end{array}$ & 0.101 & -0.068 & -0.009 & -0.064 & 0.027 & 0.085 \\
\hline $\begin{array}{l}\text { Markets nat. + } \\
\text { internat. }\end{array}$ & -0.078 & 0.041 & 0.007 & 0.037 & $0.096^{* * *}$ & $0.085^{* *}$ \\
\hline $\begin{array}{l}\text { Markets only } \\
\text { international }\end{array}$ & -0.154 & 0.169 & $0.115^{*}$ & 0.129 & 0.010 & -0.042 \\
\hline Concentration & 0.012 & -0.008 & -0.006 & 0.010 & -0.003 & 0.020 \\
\hline Competition & 0.156 & 0.161 & $0.198^{* *}$ & 0.093 & 0.105 & $0.527^{*}$ \\
\hline Variety & -21.119 & 3.247 & 0.353 & -1.472 & $10.021^{*}$ & -7.240 \\
\hline Extremely urban* & 0.088 & $-0.252^{*}$ & 0.006 & 0.032 & $0.091^{*}$ & -0.007 \\
\hline Very urban* & 0.167 & -0.045 & 0.028 & 0.103 & 0.042 & -0.011 \\
\hline $\begin{array}{l}\text { Moderately } \\
\text { urban* }\end{array}$ & 0.043 & 0.007 & 0.004 & 0.095 & 0.021 & 0.000 \\
\hline Barely urban* & -0.018 & 0.024 & -0.008 & -0.030 & -0.000 & -0.045 \\
\hline Rural* & Ref.cat. & Ref.cat. & Ref.cat. & Ref.cat. & Ref.cat. & Ref.cat. \\
\hline $\begin{array}{l}\text { Diversity of } \\
\text { arrivals }\end{array}$ & $-1.838^{* * *}$ & -0.377 & -0.239 & $-0.803^{* *}$ & -0.307 & $-1.452^{* * *}$ \\
\hline $\begin{array}{l}\text { Highly paid } \\
\text { arrivals (100) }\end{array}$ & $0.472^{* * *}$ & $0.218^{* *}$ & $0.096^{* *}$ & -0.012 & 0.007 & $0.095^{* *}$ \\
\hline $\begin{array}{l}\text { Diversity of } \\
\text { highly paid arr. }\end{array}$ & -0.356 & -0.068 & $-0.193^{* * *}$ & $-0.214^{* *}$ & $-0.135^{*}$ & $-0.169^{* *}$ \\
\hline $\begin{array}{l}\text { Arrivals from } \\
\text { same sector } \\
(100)\end{array}$ & -0.052 & 0.081 & -0.004 & $0.063^{*}$ & 0.007 & 0.009 \\
\hline $\begin{array}{l}\text { Provincial } \\
\text { dummies }\end{array}$ & Yes & & Yes & & Yes & \\
\hline Constant & 0.094 & -0.043 & 0.004 & -0.061 & -0.066 & 0.008 \\
\hline
\end{tabular}


Table 8 continued

\begin{tabular}{llllllc}
\hline Productivity & $\begin{array}{l}(6 \mathrm{a}, \mathrm{IV}) \\
\text { science-based }\end{array}$ & $\begin{array}{l}(6 \mathrm{~b}, \mathrm{IV}) \\
\text { specialized } \\
\text { suppliers }\end{array}$ & $\begin{array}{l}(6 \mathrm{c}, \mathrm{IV}) \\
\text { scale-intensive }\end{array}$ & $\begin{array}{l}\text { (6d, IV) } \\
\text { supplier- } \\
\text { dominated }\end{array}$ & $\begin{array}{l}\text { (6e, IV) }(6 \mathrm{f}, \text { IV) tradi- } \\
\text { KIBS }\end{array}$ & $\begin{array}{l}\text { tional services } \\
\text { tionaly }\end{array}$ \\
\hline$N$ & 350 & 457 & 1675 & 432 & 942 & 1709 \\
Pseudo $R^{2}$ & 0.569 & 0.196 & 0.242 & 0.469 & 0.184 & 0.262 \\
\hline
\end{tabular}

Variables marked with a * are dummy variables. $T$ statistics are available upon request. For competition, variety, and diversity variables, high values indicate a low degree of the concept in question. * $p<0.05$, $* * p<0.01, * * * p<0.001$

Table 9 Summary of results for the diversity of labour inflow

A positive sign indicates a

positive impact of diversity,

contrary to the tables above,

which report a

Hirschman-Herfindal

coefficient, where high values

indicate low diversity and vice

versa. ++ indicates statistically

significant effects at $\alpha=1 \%$. +

and - indicate statistically

insignificant effects at $\alpha=1 \%$

\begin{tabular}{lll}
\hline & All & Highly paid \\
\hline Innovation & & \\
$\quad$ Service new to firm & + & ++ \\
Goods and services new to market & + & + \\
Process & + & - \\
Productivity & & \\
All & ++ & ++ \\
Small & ++ & + \\
Medium & - & ++ \\
Large & - & + \\
Science-based & ++ & + \\
Specialized suppliers & + & + \\
Scale-intensive & + & ++ \\
Supplier-dominated & ++ & ++ \\
KIBS & + & + \\
Traditional services & ++ & ++ \\
\hline
\end{tabular}

\subsection{Results for other variables}

Finally, we will briefly discuss the other variables at the firm and regional level in turn. As expected, R\&D expenditure has a positive effect on the probability of innovating (Tables 4, 5). However, the amount of R\&D staff does not, yielding instead a negative coefficient. This is probably because it is the ratio of expenditure per employee also matters. Total firm size, on the other hand, does have a statistically significant relationship with process innovations and productivity, with larger firms having a higher probability for process innovations or to have a higher productivity. However, this effect is not perceptible for service innovations new to the firm; ceteris paribus, medium firms are less likely than small firms and large firms to attain these kinds of innovations. For products new to the market, the picture is even the other way around, although most effects are not statistically significant: the smallest firms seem to have the highest probability of introducing such innovations. Some studies argue this strategy offers small firms the best chances of survival compared to their larger competitors (Mosey 2005). Contrary to our simple model, our intuition, and existing 
Table 10 Summary of agglomeration effects

\begin{tabular}{|c|c|c|c|c|c|c|}
\hline \multirow[t]{2}{*}{ Pavitt sector } & \multicolumn{2}{|l|}{ Concentration } & \multicolumn{2}{|c|}{ Competition } & \multicolumn{2}{|l|}{ Diversity } \\
\hline & Good & $\mathrm{Bad}$ & Good & Bad & Good & Bad \\
\hline Science-based & $\begin{array}{l}\text { Productivity } \\
\quad(\mathrm{FR})\end{array}$ & & Service & $\begin{array}{l}\text { Productivity } \\
\text { (FR) }\end{array}$ & & \\
\hline Specialized suppliers & & & & & Service & \\
\hline Scale-intensive & & & Service & $\begin{array}{l}\text { Productivity } \\
\quad \text { (SR) }\end{array}$ & Market & \\
\hline Supplier-dominated & & & Market & & & \\
\hline $\begin{array}{l}\text { Knowledge-intensive } \\
\text { business sectors } \\
\text { (KIBS) }\end{array}$ & Service & & Market & Process & & $\begin{array}{l}\text { Productivity } \\
\text { (SR) }\end{array}$ \\
\hline Traditional services & & & & $\begin{array}{l}\text { Productivity } \\
\text { (SR and } \\
\text { FR) }\end{array}$ & $\begin{array}{l}\text { Market, } \\
\text { process }\end{array}$ & \\
\hline
\end{tabular}

Results indicated are those significant at $\alpha=1 \%$. Results for productivity are labelled with FR for the full regression (4) and SR for the sectoral regressions (6a-f). Both competition and diversity have positive effects when the coefficient has a negative sign, and vice versa

literature (Brusoni et al. 2006; Rochina-Barrachina et al. 2008; Vivero 2002), the presence of process innovations is not significantly related to an increase in productivity.

The absorptive capacity variables, which follow the firm size variables in all tables, show many highly significant results, and they all have the expected signs. This is in line with previous work on the Dutch CIS (e.g. Smit et al. 2015). The agglomeration variables fare less well, even though we allow them to vary by Pavitt sector. Most of these results are statistically insignificant or significant but negative. Table 10 lists the statistically significant effects found, by sector and direction. Supplier-dominated industries never experience agglomeration advantages or disadvantages, apparently; competition has the largest number of significant effects, though as many are positive as negative. Concentration and diversity are always positive in our estimation, but for different sectors, underlining why the Marshall versus Jacobs debate is so difficult to bring to an end (Beaudry and Schiffauerova 2009; de Groot et al. 2015; van der Panne and van Beers 2006). Note that there are four differences and only one match between the results on productivity from regression (4), where the agglomeration variables were interacted with the Pavitt sectors, but the other variables were not, and those from regression (6), where the coefficients of all variables were allowed to vary by sector. It appears the amount of heterogeneity between sectors is so large, that assuming some variables to have the same effect across all sectors leads to false positives and negatives where agglomeration is concerned. These results call for caution when employing studies of agglomeration effects for regional policy.

We could conclude that agglomeration seems not to influence innovation or productivity much, given that we already control for firm-level variables (as in Smit et al. 2015). We also argued that the labour mobility variables to some degree pry open the black box of knowledge spillovers. Table 11 shows for our analysis of productivity the agglomeration and labour mobility variables, allowing us to track the changes in 
Table 11 Effect on agglomeration variables of including labour mobility

\begin{tabular}{|c|c|c|c|c|c|c|}
\hline Productivity, OLS & (7a) & & (7b) & & $(7 c=4)$ & \\
\hline Conc (science based) & $0.044^{* * *}$ & $(6.86)$ & $0.046^{* * *}$ & $(7.18)$ & $0.045^{* * *}$ & $(7.07)$ \\
\hline Conc (spec. suppliers) & -0.008 & $(-1.09)$ & -0.006 & $(-0.85)$ & -0.008 & $(-1.04)$ \\
\hline Conc (scale-intensive) & -0.003 & $(-0.90)$ & -0.003 & $(-0.95)$ & -0.005 & $(-1.51)$ \\
\hline Conc (supplier-dominated) & 0.008 & (1.13) & 0.010 & $(1.37)$ & 0.010 & $(1.44)$ \\
\hline Conc (KIBS) & -0.037 & $(-1.53)$ & -0.038 & $(-1.56)$ & -0.043 & $(-1.77)$ \\
\hline Conc (traditional serv.) & 0.021 & $(1.18)$ & 0.021 & $(1.17)$ & 0.020 & $(1.12)$ \\
\hline Comp (science based) & $0.326^{* * *}$ & $(4.14)$ & $0.334^{* * *}$ & $(4.26)$ & $0.325^{* * *}$ & $(4.16)$ \\
\hline Comp (spec. suppliers) & 0.016 & $(0.22)$ & 0.019 & $(0.26)$ & 0.034 & $(0.47)$ \\
\hline Comp (scale-intensive) & 0.117 & $(1.68)$ & 0.132 & $(1.90)$ & $0.141^{*}$ & $(2.03)$ \\
\hline Comp (supplier-dominated) & 0.096 & $(1.03)$ & 0.110 & $(1.18)$ & 0.101 & (1.09) \\
\hline Comp (KIBS) & 0.005 & $(0.03)$ & 0.002 & $(0.01)$ & -0.000 & $(-0.00)$ \\
\hline Comp (traditional serv.) & $0.758^{* * *}$ & $(3.54)$ & $0.743^{* * *}$ & $(3.48)$ & $0.763^{* * *}$ & (3.59) \\
\hline Vary (science based) & -19.728 & $(-0.51)$ & -26.216 & $(-0.68)$ & -29.689 & $(-0.78)$ \\
\hline Vary (spec. suppliers) & -12.425 & $(-0.26)$ & -10.159 & $(-0.21)$ & -14.321 & $(-0.30)$ \\
\hline Vary (scale-intensive) & 1.564 & $(0.37)$ & 1.843 & $(0.44)$ & 1.442 & $(0.35)$ \\
\hline Vary (supplier-dominated) & 1.656 & $(0.11)$ & 0.920 & $(0.06)$ & 3.476 & $(0.23)$ \\
\hline Vary (KIBS) & 3.493 & $(0.85)$ & 2.886 & $(0.71)$ & 2.900 & $(0.71)$ \\
\hline Vary (traditional serv.) & 6.848 & $(0.95)$ & 5.198 & $(0.73)$ & 5.925 & $(0.83)$ \\
\hline Extremely urban* & 0.028 & $(1.14)$ & 0.028 & $(1.13)$ & 0.029 & $(1.16)$ \\
\hline Very urban* & 0.030 & $(1.47)$ & 0.031 & $(1.50)$ & 0.030 & $(1.45)$ \\
\hline Moderately urban* & 0.012 & $(0.62)$ & 0.012 & $(0.61)$ & 0.012 & $(0.63)$ \\
\hline Barely urban* & -0.018 & $(-1.01)$ & -0.019 & $(-1.05)$ & -0.018 & $(-1.01)$ \\
\hline Rural* & Ref.cat. & & Ref.cat. & & Ref.cat. & \\
\hline Arrivals (100) & & & $0.004^{* * *}$ & $(4.08)$ & & \\
\hline Diversity of arrivals & & & $-0.722^{* * *}$ & $(-6.61)$ & $-0.573^{* * *}$ & $(-5.06)$ \\
\hline Highly paid arrivals (100) & & & & & $0.036^{* * *}$ & $(4.41)$ \\
\hline Diversity of highly paid arr. & & & & & $-0.192^{* * *}$ & $(-5.92)$ \\
\hline $\begin{array}{l}\text { Arrivals from same sector } \\
\text { (100) }\end{array}$ & & & & & 0.002 & $(0.61)$ \\
\hline Constant & $-0.167^{* * *}$ & $(-3.74)$ & $-0.112^{*}$ & $(-2.47)$ & -0.043 & $(-0.93)$ \\
\hline$N$ & 5565 & & 5565 & & 5565 & \\
\hline Adj. $R^{2}$ & 0.269 & & 0.276 & & 0.282 & \\
\hline
\end{tabular}

The third column repeats regression $4 \mathrm{c}$, for easy reference. The only change in significance levels is bolded $* p<0.05 ; * * p<0.01 ; * * * p<0.001$

the agglomeration variables when labour mobility is taken into account. We can conclude from these results that the agglomeration variables adjust only minimally once labour mobility is taken into account - they seem quite orthogonal. Labour mobility may have a statistically significant impact on knowledge creation (innovation) and on productivity, but agglomeration externalities go beyond this specific type of spillovers - taking them out of the black box leaves enough inside. Phrased differ- 
ently, traditional variables measuring agglomeration externalities don't capture the knowledge flows embedded in labour mobility.

Finally, our urbanization variable shows barely any significant results, with just three exceptions: specialized suppliers in extremely urban areas have a significantly lower productivity than those in rural areas, whereas KIBS fare better in extremely urban areas; and innovations new to the market are more likely to originate from the urban fringe (moderately or barely urban) than from rural areas, yet downtown areas do not stand out in this case. Presumably, our other variables have already taken care of all important spatial variations - that is, the firm variables have covered the sorting effects (Combes et al. 2012) and the agglomeration variables covered the other benefits of locating in a higher-density area.

\section{Conclusions}

We have analysed a particular mechanism through which firms can acquire new knowledge, relating the quantity and diversity of labour flows to innovation and productivity of the receiving firm. First of all, our results show statistically significant and positive effects for employees taken from other firms, indicating employee mobility is indeed an active contributor to the success of the receiving firm. Secondly, we do not see an additional bonus from employees from 'donor firms' within the same 3-digit sector. If the sectoral origin does not matter, this indicates an influx of 'new blood' is important for new ideas and creativity beyond sector-specific knowledge-preventing lock-in. We thus confirm the findings of Rosenkopf and Almeida (2003) and Song et al. (2003). This underlines the by now generally heard advice for regional policy makers to stimulate a diverse local economy, with space for related variety or spontaneous 'smart' specialization (Duranton and Puga 2000; Asheim et al. 2011; Foray 2015).

The diversity of new employees also matters across the board, sometimes for all employees, sometimes particularly for the higher-paid, more valuable employees. In general, these effects are even more consistently significant than the total flow of employees. We interpret this as proof of the importance of a variety of knowledge, which leads to new combinations and again prevents lock-in. Hence, regional policy should facilitate and stimulate the exchange of labour in the local economy.

The general agglomeration variables show predominantly insignificant results, and their role is easily overestimated in (theoretical) literature (cf. Eriksson and Lindgren 2009), and thus also in regional policy. Investigating a specific channel for knowledge flows, as we did in the labour mobility variables, did not adjust these results. Hence, more analysis of the mechanics of knowledge spillovers is needed as a way out of the threatening deadlock in agglomeration studies, where statistically significant results are found for different variables, but without identification of the underlying mechanisms. Surprisingly, the urbanization effect, well confirmed in the literature (Melo et al. 2009), turns out to be negligible; perhaps the Netherlands as a whole functions as one urban playing field in this respect (contra van Oort 2004).

We should express some caution, as always. When our results indicate flows within the same 3-digit sector are not present, this result is based upon our analysis of a 4-year 
setting in the rather densely populated Netherlands in the early $2000 \mathrm{~s}^{23}$ The same constraints hold, of course, for all other results found. Moreover, where we found positive, statistically significant effects for labour flows in general, the coefficients we found, were economically small, with marginal effects $<0.01$. As an example, adding a hundred new highly paid employees from other firms increases the chance of innovating by less than $0.6 \%$, ceteris paribus. Compared to the other factors and their coefficients, this is a tiny effect, even if it is statistically different from zero (Ziliak and McCloskey 2008).

Finally, we should again point at the large underlying heterogeneity in the results. We see sizeable variation among the results, whether we look at innovation or productivity. Both by size class of the firms and by broad Pavitt sector, there is a lack of consistency in the estimations. Agglomeration externalities of any type, including knowledge spillovers through labour mobility, vary so much among different types of firms that it is risky, especially from a policy perspective, to draw ex ante conclusions on their strength or to devise generic policies from them.

Acknowledgements We heartily thank Statistics Netherlands for their constructive efforts in making microdata available to researchers. We also thank Nikolay Zubanov (LEED seminar in Porto, June 2011) and Martin Henning (Geography of Innovation conference in Utrecht, January 2014), as well as our anonymous reviewers, for their critical and useful comments.

Open Access This article is distributed under the terms of the Creative Commons Attribution 4.0 International License (http://creativecommons.org/licenses/by/4.0/), which permits unrestricted use, distribution, and reproduction in any medium, provided you give appropriate credit to the original author(s) and the source, provide a link to the Creative Commons license, and indicate if changes were made.

${ }^{23}$ It is possible the effect is different over a different time period, or in a different geographical setting. In our opinion, these restrictions are not emphasized enough in the existing literature, where geographically, historically, and methodologically constrained results are all too easily generalized, leaving it to metaanalyses to sort things out. 


\section{Appendix: descriptives}

See Tables 12, 13.

Table 12 Mean and standard deviation of dependent and independent variables

\begin{tabular}{lrrl}
\hline Variable & Mean & SD & Variable \\
\hline Service innovation & 0.11 & 0.32 & Dummy \\
Process innovation & 0.24 & 0.43 & Dummy \\
Productivity & 0.21 & 0.55 & Ratio scale \\
R\&D expenditure & 1.06 & 2.18 & Log of $€$ \\
R\&D staff & 0.19 & 0.82 & Log \\
Firm size & 1.72 & 1.01 & Classes 1-5 \\
Firm engages in training & 0.17 & 0.38 & Dummy \\
New mngmt techniques & 0.16 & 0.37 & Dummy \\
New org. structures & 0.23 & 0.42 & Dummy \\
New marketing strategies & 0.07 & 0.26 & Dummy \\
Firm collaborates on innovation & 0.16 & 0.36 & Dummy \\
Firm receives govt support & 0.14 & 0.34 & Dummy \\
Markets nat. + internat. & 0.40 & 0.49 & Dummy \\
Markets only international & 0.05 & 0.21 & Dummy \\
Concentration & 1.57 & 2.27 & Ratio scale \\
Competition & 0.09 & 0.17 & Ratio scale, 0-1 \\
Variety & 0.03 & 0.01 & Ratio scale, 0-1 \\
Urbanization & 3.29 & 1.32 & Classes 1-5 \\
Arrivals (in hundreds of employees) & 153.12 & 622.07 & Ratio scale \\
Diversity of arrivals & 0.05 & 0.08 & Ratio scale, 0-1 \\
Highly paid arrivals (100) & 28.46 & 94.48 & Ratio scale \\
Diversity of highly paid arr. & 0.21 & 0.27 & Ratio scale, 0-1 \\
Arrivals from same sector (100) & 30.84 & 187.99 & Ratio scale \\
\hline
\end{tabular}




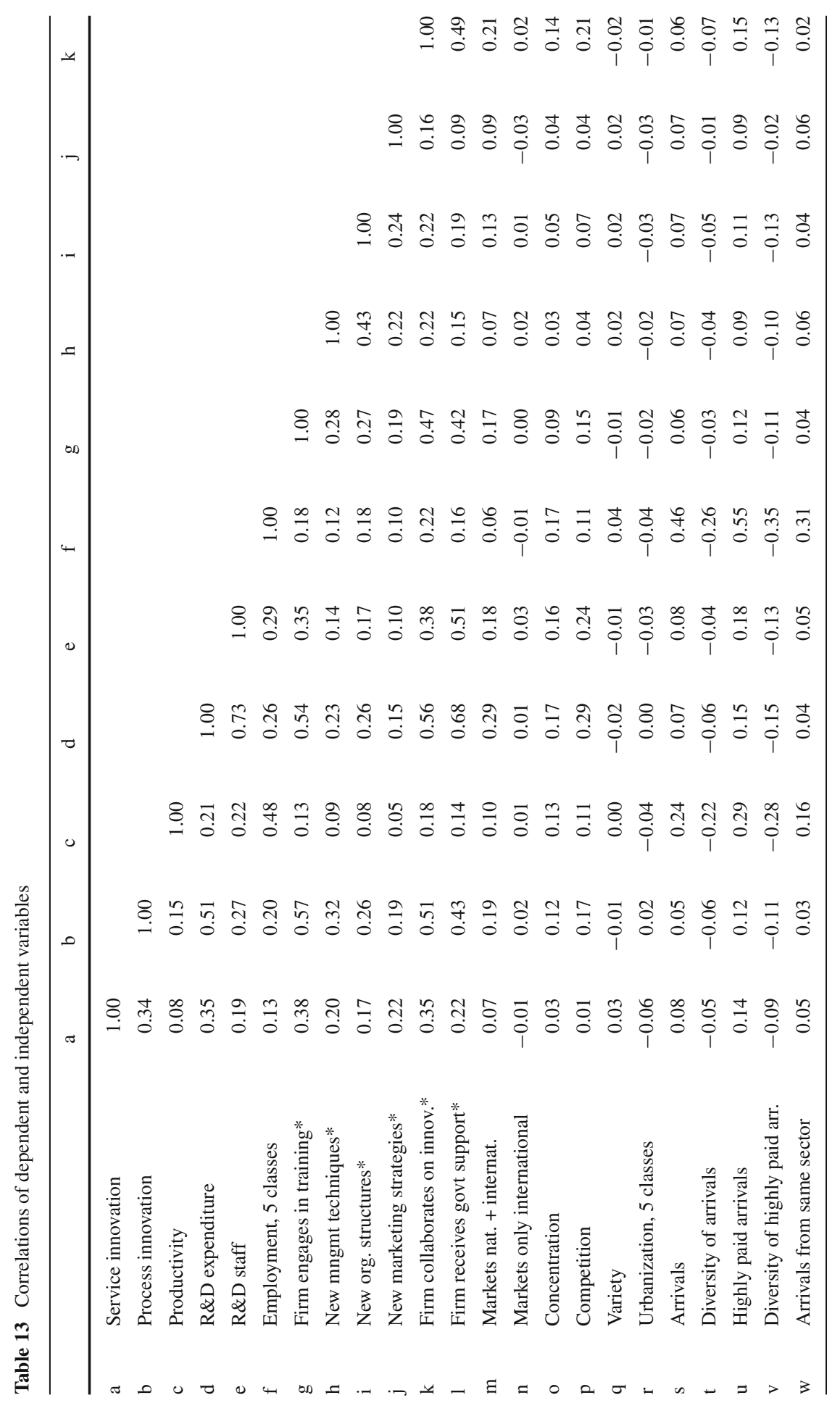




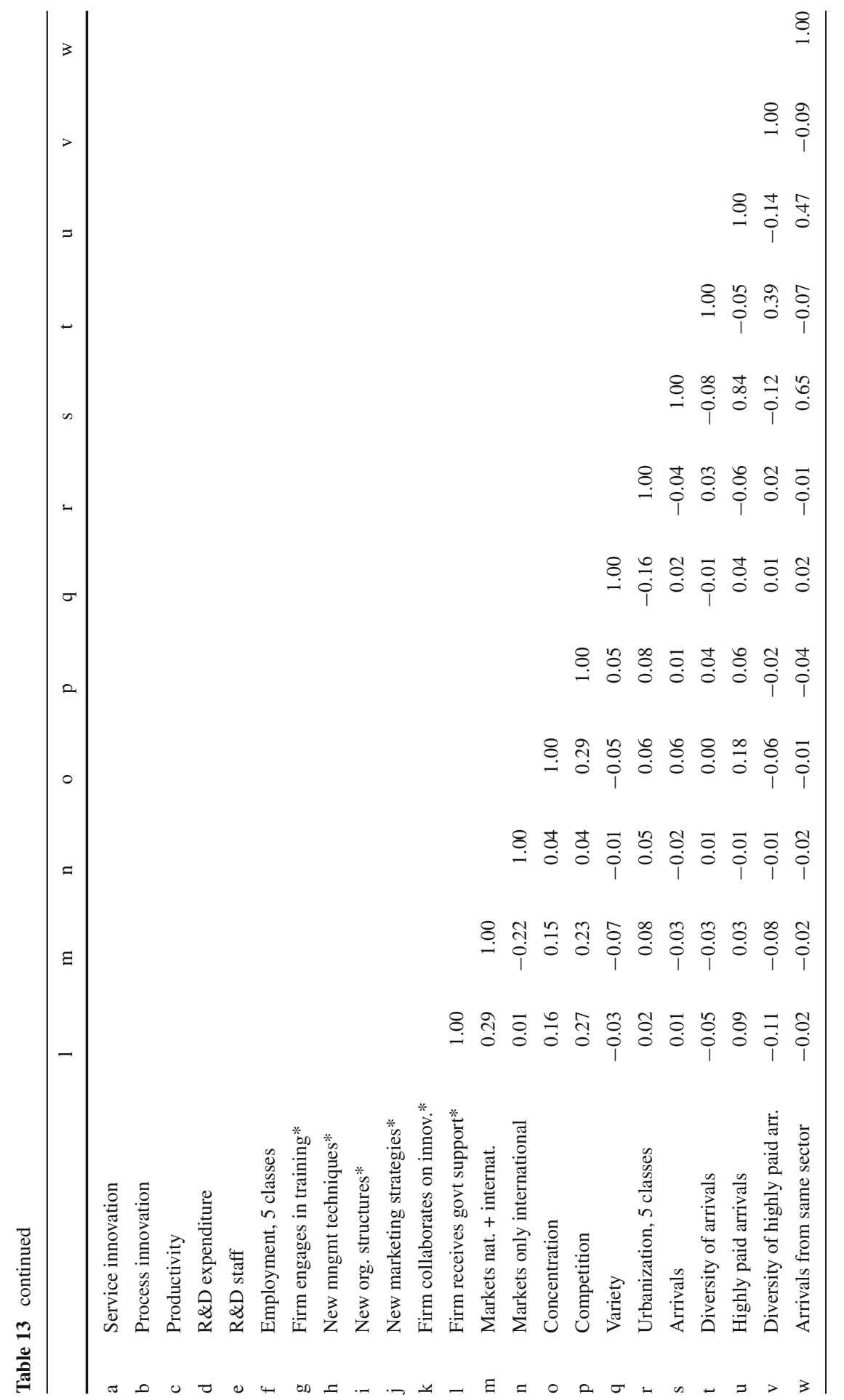




\section{References}

Abreu M, de Groot HLF, Florax RJGM (2005) A meta-analysis of bèta-convergence: the legendary $2 \%$. J Econ Surv 19:389-420

Abreu M, Grinevich V, Kitson M, Savona M (2008) Absorptive capacity and regional patterns of innovation. Department of Innovation, Universities and Skills, London

Aghion P, Howitt P (1994) Growth and unemployment. Rev Econ Stud 61:477-494. doi:10.2307/2297900

Anselin L, Varga A, Acs Z (1997) Local geographic spillovers between university research and high technology innovations. J Urban Econ 42:422-448

Asheim BT, Boschma R, Cooke P (2011) Constructing regional advantage: platform policies based on related variety and differentiated knowledge bases. Reg Stud 45:893-904. doi:10.1080/00343404. 2010.543126

Beaudry C, Breschi S (2003) Are firms in clusters really more innovative? Econ Innovation New Technol 12(4):325-42

Beaudry C, Schiffauerova A (2009) Who's right, Marshall or Jacobs? The localization versus urbanization debate. Res Policy 38:318-337. doi:10.1016/j.respol.2008.11.010

Beckstead D, Brown WM, Gellatly G (2008) The left brain of north American cities: scientists and engineers and Urban growth. Int Reg Sci Rev 31(3):304-38. doi:10.1177/0160017608318521

Bishara ND, Westermann-Behaylo M (2012) The law and ethics of restrictions on an employee's postemployment mobility. Am Bus Law J 49:1-61. doi:10.1111/j.1744-1714.2011.01128.x

Bjerke L (2012) Knowledge flows across space and firms. Ph.D. thesis. Jönköping International Business School, Jönköping

Boer H, Gertsen F (2003) From continuous improvement to continuous innovation: a (retro)(per)spective. Int J Technol Manag 26:805-827. doi:10.1504/IJTM.2003.003391

Boschma RA (2005) Proximity and innovation: a critical assessment. Reg Stud 39:61-74

Boschma RA, Eriksson R, Lindgren U (2009) How does labour mobility affect the performance of plants? The importance of relatedness and geographical proximity. J Econ Geogr 9:169-190

Breschi S, Lissoni F (2001) Knowledge spillovers and local innovation systems: a critical survey. Ind Corp Change 10:975-1005

Brusoni S, Cefis E, Orsenigo L (2006) Innovate or die? A critical review of the literature on innovation and performance. Centro di Ricerca sui Processi di Innovazione e Internazionalizzazione, WP \#179. Milano, August 2006

Cainelli G, Iacobucci D (2012) Agglomeration, related variety, and vertical integration. Econ Geogr 88:255277. doi:10.1111/j.1944-8287.2012.01156.x

Castells M (1996) The rise of the network society, the information age: economy, society and culture. Blackwell, Oxford

Coad A, Daunfeldt S-O, Johansson D, Wennberg K (2014) Whom do high-growth firms hire? Ind Corp Change 23:293-327. doi:10.1093/icc/dtt051

Cohen WM, Levinthal DA (1990) Absorptive capacity: a new perspective on learning and innovation. Adm Sci Q 35:128-185

Combes P-P, Duranton G (2006) Labour pooling, labour poaching, and spatial clustering. Reg Sci Urban Econ 36:1-28. doi:10.1016/j.regsciurbeco.2005.06.003

Combes P-P, Duranton G, Gobillon L, Puga D, Roux S (2012) The productivity advantages of large cities: distinguishing agglomeration from firm selection. Econometrica 80(6):2543-94. doi:10.3982/ECTA8442

de Groot HLF, Poot J, Smit MJ (2015) Which agglomeration externalities matter most and why? J Econ Surv 30:756-782. doi:10.1111/joes.12112

Duranton G, Puga D (2001) Nursery cities: urban diversity, process innovation, and the life cycle of products. Am Econ Rev 91:1454-1477

Duranton G, Puga D (2000) Diversity and specialisation in cities: Why, where and when does it matter? Urban Stud 37:533-555

Dyer JH, Singh H (1998) The relational view: cooperative strategy and sources of interorganizational competitive advantage. Acad Manag Rev 23:660-679

Eeckhout J, Jovanovic B (2002) Knowledge spillovers and inequality. Am Econ Rev 92:1290-1307

Eriksson R, Lindgren U (2009) Localized mobility clusters: impacts of labour market externalities on firm performance. J Econ Geogr 9:33-53. doi:10.1093/jeg/lbn025

Ettlie JE (1980) Manpower flows and the innovation process. Manag Sci 26:1086-1095. doi:10.1287/mnsc. 26.11.1086 
Evangelista R (2000) Sectoral patterns of technological change in services. Econ Innov New Technol 9:183-222. doi:10.1080/10438590000000008

Foray D (2015) Smart specialisation: opportunities and challenges for regional innovation policy, regions and cities. Routledge, London

Freel MS, Robson PJA (2004) Small firm innovation, growth and performance evidence from Scotland and Northern England. Int Small Bus J 22:561-575. doi:10.1177/0266242604047410

Frenken K, van Oort FG, Verburg T (2007) Related variety, unrelated variety and regional economic growth. Reg Stud 41:685-697

Glaeser EL, Kallal HD, Scheinkman JA, Shleifer A (1992) Growth in cities. J Polit Econ 100:1126-1152

Grabher G (1993) The embedded firm. Routledge, London

Groot SPT, de Groot HLF, Smit MJ (2014) Regional wage differences in the Netherlands: micro-evidence on agglomeration externalities. J Reg Sci 54:503-523

Hall PG (1998) Cities in civilization. Pantheon Books, New York

Jacobs J (1969) The economy of cities. Random House, New York

Jaffe AB, Trajtenberg M, Henderson R (1993) Geographic localization of knowledge spillovers as evidenced by patent citations. Q J Econ 108:577-598

Kaiser U, Kongsted HC, Rønde T et al. (2008) Labor mobility and patenting activity. Univ. Cph. Dep. Econ. Cent. Appl. Microeconometrics CAM Working Paper 7

Keijl S, Gilsing VA, Knoben J, Duysters G (2016) The two faces of inventions: the relationship between recombination and impact in pharmaceutical biotechnology. Res Policy 45:1061-1074. doi:10.1016/ j.respol.2016.02.008

Kleinknecht A, Verspagen B (1989) R\&D and market structure: the impact of measurement and aggregation problems. Small Bus Econ 1:297-301

Klepper S (2007) Disagreements, spinoffs, and the evolution of Detroit as the capital of the US automobile industry. Manag Sci 53:616-631

Kogut B, Zander U (1992) Knowledge of the firm, combinative capabilities, and the replication of technology. Organ Sci 3:383-397. doi:10.1287/orsc.3.3.383

Kronenberg K, Carree M (2010a) Job and residential mobility in the Netherlands: the influence of human capital, household composition and location. MPRA 25840, 2010. http://mpra.ub.uni-muenchen.de/ $25840 /$

Kronenberg K, Carree M (2010b) The effects of workforce composition, labor turnover, and the qualities of entering and exiting workers on productivity growth. MPRA 25844, 2010. https://mpra.ub. uni-muenchen.de/25844/

Lane PJ, Koka BR, Pathak S (2006) The reification of absorptive capacity: a critical review and rejuvenation of the construct. Acad Manag Rev 31:833-863

Lane PJ, Lubatkin M (1998) Relative absorptive capacity and interorganizational learning. Strateg Manag J 19:461-477

Levinsohn J, Petrin A (2003) Estimating production functions using inputs to control for unobservables. Rev Econ Stud 70(2):317-341

Maliranta M, Mohnen P, Rouvinen P (2009) Is inter-firm labor mobility a channel of knowledge spillovers? Evidence from a linked employer-employee panel. Ind Corp Change 18:1161-1191. doi:10.1093/icc/ dtp031

Malmberg A, Power D (2005) (How) do (firms in) clusters create knowledge? Ind Innov 12:409-431. doi:10. 1080/13662710500381583

Melo PSC, Graham DJ, Noland RB (2009) A meta-analysis of estimates of urban agglomeration externalities. Reg Sci Urban Econ 39:332-342

Möhlmann JL (2013) Globalization and productivity: micro-evidence on heterogeneous firms, workers and products. PhD thesis, Vrije Universiteit, 2013. http://dare.ubvu.vu.nl/handle/1871/39936

Mosey S (2005) Understanding new-to-market product development in SMEs. Int J Oper Prod Manag 25:114-130. doi:10.1108/01443570510576994

Neffke F, Henning M, Boschma RA, Lundquist K-J, Olander L-O (2011) The dynamics of agglomeration externalities along the life cycle of industries. Reg Stud 45:49-65. doi:10.1080/00343401003596307

Nelson RR, Winter SG (2009) An evolutionary theory of economic change. Harvard University Press, Cambridge

Nesta L (2008) Knowledge and productivity in the world's largest manufacturing corporations. J Econ Behav Organ 67(3-4):886-902. doi:10.1016/j.jebo.2007.08.006 
Nooteboom B (2000) Learning and innovation in organizations and economies. Oxford University Press, Oxford

Østergaard CR, Timmermans B, Kristinsson K (2011) Does a different view create something new? The effect of employee diversity on innovation. Res Policy 40:500-509. doi:10.1016/j.respol.2010.11.004

Paci R, Usai S (1999) Externalities, knowledge spillovers and the spatial distribution of innovation. GeoJournal 49:381-390. doi:10.1023/A:1007192313098

Parrotta P, Pozzoli D, Pytlikova M (2014) The nexus between labor diversity and firm's innovation. J Popul Econ 27:303-364. doi:10.1007/s00148-013-0491-7

Pavitt K (1984) Sectoral patterns of technical change: towards a taxonomy and a theory. Res Policy 13:343373

Pennings JM, Lee K, van Witteloostuijn A (1998) Human capital, social capital, and firm dissolution. Acad Manag J 41:425-440. doi:10.2307/257082

Ponds R, van Oort FG, Frenken K (2010) Innovation, spillovers and university-industry collaboration: an extended knowledge production function approach. J Econ Geogr 10:231-255

Power D, Lundmark M (2004) Working through knowledge pools: labour market dynamics, the transference of knowledge and ideas, and industrial clusters. Urban Stud 41:1025-1044. doi:10.1080/ 00420980410001675850

Reinau KH (2011) Local Clusters in a Globalized World: A Foucauldian analysis of the people in an MNC subsidiary located in a cluster. PhD thesis. Aalborg Universitet, Faculty of Engineering and Science

Rochina-Barrachina ME, Mañez JA, Sanchis-Llopis JA (2008) Process innovations and firm productivity growth. Small Bus Econ 34:147-166. doi:10.1007/s11187-008-9110-5

Rosenkopf L, Almeida P (2003) Overcoming local search through alliances and mobility. Manag Sci 49:751766

Rosenthal SS, Strange WC (2004) Evidence on the nature and sources of agglomeration economies. In: Henderson V, Thisse J-F (eds) Handbook of regional and urban economics. Elsevier, Amsterdam, pp 2119-2171

Saxenian A (1996) Inside-out: regional networks and industrial adaptation in Silicon Valley and Route 128. Cityscape 2(2):41-60

Saxenian A (1994) Regional advantage: culture and competition in Silicon Valley and route 128. Harvard University Press, Cambridge

Schubert T, Andersson M (2015) Old is gold? The effects of employee age on innovation and the moderating effects of employment turnover. Econ Innov New Technol 24:95-113

Schumpeter JA (1934) The theory of economic development. Oxford University Press, London

Sheshinski E (1967) Tests of the "learning by doing" hypothesis. Rev Econ Stat 49(4):568-578

Smit MJ, Abreu M, de Groot HLF (2015) Micro-evidence on the determinants of innovation in the Netherlands: the relative importance of absorptive capacity and agglomeration externalities. Pap Reg Sci 94:249-272

Smit MJ, de Groot HLF (2013) Stocking up: the role of temporal and spatial R\&D stocks. Eur Plan Stud 21:637-665. doi:10.1080/09654313.2012.745266

Somaya D, Williamson IO, Lorinkova N (2008) Gone but not lost: the different performance impacts of employee mobility between cooperators versus competitors. Acad Manag J 51:936-953. doi:10.5465/ AMJ.2008.34789660

Song J, Almeida P, Wu G (2003) Learning-by-Hiring: When is mobility more likely to facilitate interfirm knowledge transfer? Manag Sci 49:351-365

Stoyanov A, Zubanov N (2012) Productivity spillovers across firms through worker mobility. Am Econ J Appl Econ 4:168-198. doi:10.1257/app.4.2.168

Trax M, Brunow S, Suedekum J (2015) Cultural diversity and plant-level productivity. Reg Sci Urban Econ 53:85-96. doi:10.1016/j.regsciurbeco.2015.05.004

Unger JM, Rauch A, Frese M, Rosenbusch N (2011) Human capital and entrepreneurial success: a metaanalytical review. J Bus Ventur 26:341-358. doi:10.1016/j.jbusvent.2009.09.004

van der Panne G, van Beers C (2006) On the Marshall-Jacobs controversy: it takes two to tango. Ind Corp Change 15:877-890

van Oort FG, de Geus S, Dogaru T (2015) Related variety and regional economic growth in a cross-section of European urban regions. Eur Plan Stud 23:1110-1127

van Oort FG (2004) Urban growth and innovation: spatially bounded externalities in the Netherlands. Ashgate, Aldershot 
van Oort FG (2002) Innovation and agglomeration economies in the Netherlands. Tijdschr Voor Econ En Soc Geogr 93:344-360

Vinding AL (2006) Absorptive capacity and innovative performance: a human capital approach. Econ Innov New Technol 15:507-517. doi:10.1080/10438590500513057

Vivero RL (2002) The impact of process innovations on firm's productivity growth: the case of Spain. Appl Econ 34:1007-1016. doi:10.1080/00036840010019684

Youl Lee S, Florida R, Acs ZJ (2004) Creativity and entrepreneurship: a regional analysis of new firm formation. Reg Stud 38:879-891

Zahra SA, George G (2002) Absorptive capacity: a review, reconceptualization, and extension. Acad Manag Rev 27:185-203

Ziliak ST, McCloskey DN (2008) The cult of statistical significance: how the standard error costs us jobs, justice, and lives. University of Michigan Press, Ann Arbor 